\title{
VESAYET ALTINDAKİ KÜÇÜĞÜN KORUMA AMACIYLA ÖZGÜRLÜĞÜNÜ̉N KISITLANMASI (TMK 446)
}

\author{
Dr. S. Hülya IMAMOĞLU
}

\begin{abstract}
I. Giriş
$\mathrm{Bu}$ çalışmanın konusunu, vesayet altındaki küçügün koruma amacıyla özgürlüğünün kısıtlanması teşkil etmektedir. Konu çerçevesinde ağırlıklı olarak vesayet altındaki küçügün koruma amacıyla özgürlügünün kısıtlanmasının şartları incelenmiştir ve konunun gerekli kıldığı ölçüde bu husustaki yetki ve usul üzerinde durulmuştur. İnceleme sırasında önce anılan kurumun Türk Medeni Kanunu'ndaki düzenleniş biçimi, hukuki niteliği ve vasinin vesayeti altında bulunan küçüğe özen gösterme yükümü ile ilişkisi ele alınmıştır.

II. Vesayet Altındaki Küçüğün Koruma Amacıyla Özgürlüğünün Kısıtlanmasının Türk Medeni Kanunu'ndaki Düzenleniş Biçimi

Vesayet altındaki küçüğün koruma amacıyla özgürlüğünün kısıtlanması, 4721 sayılı Türk Medeni Kanunu'nun vesayet kısmında, vesayetin yürütülmesine ilişkin ikinci bölümün vasinin görevlerini düzenleyen birinci ayrımında, 446. maddede yer almaktadır. Vasinin vesayeti altında bulunan küçüğe özen gösterme yükümünü öngören 445 . maddeyi takip eden hüküm olarak 446. madde, şu düzenlemeyi içermektedir: "Küçüklerin koruma amaciyla bir kuruma yerleştirilmesine vasinin başvurusu üzerine vesayet makamı veya gecikmesinde sakınca bulunan hallerde bizzat vasi karar verir ve durumu derhal vesayet makamına bildirir (f.1). Bunun dişında usul ve yetkiyle ilgili konularda kısıtlı olsun veya olmasın erginlerin korunması amacıyla özgürlüklerinin kısıtlanmasına ilişkin hükümler uygulanır (f. 2). Onaltı yaşını doldurmamış çocuk bu konuda mahkemeye bizzat başvuramaz (f. 3)".
\end{abstract}

Ankara Üniversitesi Hukuk Fakültesi Medenî Hukuk Anabilim Dalı 
Vesayet altındaki küçüğün koruma amacıyla özgürlüğünün kısıtlanmasını düzenleyen 446. madde, eski Medeni Kanun'da mevcut değildi. Yeni bir hüküm olarak 446. maddeye ilişkin gerekçede, bu maddenin kenar başlı̆̆ıyla birlikte İsviçre Medeni Kanunu'nun 405a maddesinden aynen alındığ ifade edilmektedir ${ }^{1}$.

İsviçre Medeni Kanunu'nun 405a maddesi ise, İsviçre'de 1978 yılında yapılan revizyonun sonucudur ${ }^{2}$. Bu revizyonla diğer bazı kanunlarla birlikte esasen İsviçre Medeni Kanunu'nun vesayetle ilgili hükümleri, kısmen gözden geçirilip değiştirilmiş ve yeni düzenlemeler getirilmiştir ${ }^{3}$. Aslında sözü edilen revizyonun gerçekleştirilmesinde, İsviçre Medeni Kanunu'nun İsviçre tarafindan 1974 yılında onaylanan İnsan Haklarını ve Ana Hürriyetleri Korumaya Dair Sözleşme (Avrupa İnsan Hakları Sözleşmesi) ${ }^{4}$ ile uyumlulaştırılması amacı, büyük ölçüde etkili olmuştur ${ }^{5}$; zira anılan

Bu hususta bkz., TBMM Tutanak Dergisi, Dönem 21, Yasama Y1lı 4, Cilt 73 (Ankara 2001), Birleşim 11-12, Sıra Sayıs1 723, s. 148.

2 Konuya ilişkin olarak bkz., Müler, Stefan: Die persönliche Fürsorge für unmündige Bevormundete (Art. 405/405a), Freiburg 1996, s. 278 vd.; Tuor, Peter/Schnyder, Bernhard/Schmid, Jörg/Rumo-Jungo, Alexandra: Das Schweizerische Zivilgesetzbuch, 12. Auflage, Zürich 2002, s. 511 vd.; Thomas Geiser, Basler Kommentar zum Schweizerischen Privatrecht (Hrsg., Honsell, Heinrich/Vogt, Nedim Peter/Geiser, Thomas), Zivilgesetzbuch I, Art. 1- 456 ZGB, 2. Auflage, Basel 2002, Vorbemerkungen zu Art. 397a-f N 1 vd., N 4 vd.

3 Bu hususta bkz., Tuor/Schnyder/Rumo-Jungo, s. 511 vd.; BSK ZGB I- Geiser, Vor Art. 397a-397f N 4 vd.; BBl 1977 III 3 vd.; krş., Spirig, Eugen: Kommentar zum Schweizerischen Zivilgesetzbuch, II. Band: Das Familienrecht (3. Auflage), 3. Abteilung: Die Vormundschaft (Art. 360-456 ZGB) (Hrsg., Peter Gauch und Jörg Schmid), Teilband II 3a, Die allgemeine Ordnung der Vormundschaft, Die fürsorgerische Freiheitsentziehung, Art. 397a-397f, Zürich 1995, Vorbemerkungen zu Art. 397a-f N 8 vd.

41 Kasım 1998 tarihinden itibaren Avrupa İnsan Hakları Sözleşmesi'nin 11 No.lu Protokol ile değişik metni yürürlükte bulunmaktadır. Sözleşme'nin 11 No.lu Protokol ile değişik metni için bkz., Gözübüyük, A. Şeref/Gölcüklü, A. Feyyaz: Avrupa İnsan Hakları Sözleşmesi ve Uygulaması, Avrupa İnsan Hakları Mahkemesi İnceleme ve Yargılama Yöntemi, 11. Ek Protokole Göre Hazırlanıp Genişletilmiş 5. Bası, Ankara 2004, s. 447 vd.; Gemalmaz, Mehmet Semih: İnsan Haklar1 Belgeleri, Cilt I, Avrupa Konseyi Birinci Bölüm, Avrupa İnsan Hakları Sözleşmesi, Protokolleri ve İlgili Diğer Belgeler, İstanbul 2003, s. 35 vd.; Akıllığlu, Tekin: Avrupa İnsan Hakları Sözleşmesi, Avrupa İnsan Hakları Mahkemesi İçtüzüğü, Başvuru Bilgileri, Ankara 2002, s. 3 vd.

$5 \quad$ Bu hususta bkz., BBl 1977 III 3 vd., 17 vd.; BSK ZGB- Geiser, Vor Art. 397a-397f N 2; ZK- Spirig, Vor Art. 397a-397f N 5 vd., N 8; Caviezel-Jost, Barbara: Die materiellen Voraussetzungen der fürsorgerischen Freiheitsentziehung (Art. 397a Abs. 1 und 2 ZGB), Dissertation, Freiburg, Stans 1988, s. 7 vd., 49 vd., 53 vd.; Suhr Brunner, Christiana: Fürsorgerische Freiheitsentziehung und Suchterkrankungen, insbesondere Drogensucht, Zürich 1994, s. 4 vd.; Lustenberger, Markus: Die fürsorgerische Freiheitsentziehung bei Unmündigen unter elterlicher Gewalt (Art. 310 / 314a ZGB), Freiburg 1987, s. 4 vd., $6 \mathrm{vd}$. 
Sözleşme'nin onaylanmasıyla birlikte İsviçre Medeni Kanunu'nun vesayete ilişkin önlemler çerçevesinde kişinin özgürlüğünün kısıtlanması sonucunu doğuran bazı hükümlerinin (mesela aArt. 406 ZGB / eMK 390 gibi) ve bu yöndeki kantonal düzenlemelerin, Sözleşme'nin özellikle 5. maddesinin hükümlerine uygun olarak yeniden gözden geçirilmesi ihtiyacı ortaya çıkmıştır. Avrupa İnsan Hakları Sözleşmesi'nin 5. maddesinde herkesin kişisel özgürlük ve güvenlik hakkına sahip olduğu esası ifade edilmiş olup, kişisel özgürlüğün ancak maddede belirtilen hallerde ve kanunda belirlenen yollarla sınırlanabileceği hükme bağlanmıştır. 1978 revizyonu açısından, anılan 5. maddenin özellikle koruma amacıyla özgürlüğün kısıtlanmasının şartlarını öngören hükümleri ile koruma amacıyla özgürlügün kısıtlanması halinde, bunun yargısal denetiminin sağlanmasına ilişkin düzenlemesi, yönlendirici olmuştur ${ }^{6}$. Bu bağlamda sözü edilen 5. maddenin hükümlerine uygun olarak İsviçre Medeni Kanunu'nun vesayet kısmına koruma amacıyla özgürlüğün kısıtlanmasına ilişkin hükümler eklenmiş ve diğer değişikliklerle birlikte velayet ve vesayet altında bulunan küçüklerin koruma amacıyla özgürlüklerinin kısıtlanması hali de gereken biçimde düzenlenmiştir ${ }^{7}$.

Bu noktada 1978 İsviçre revizyonunun en önemli sebeplerinden birini teşkil eden Avrupa İnsan Hakları Sözleşmesi'nin Türkiye tarafından da onaylanmış bulunduğuna ${ }^{9}$ ve 1982 Anayasası'nın 19. maddesinde, Sözleşme'nin yukarıda anılan 5. maddesine paralel bir düzenlemenin yer aldığına işaret edilmelidir. Nitekim yine 1978 İsviçre revizyonundan esinlenilerek 4721 sayılı Türk Medeni Kanunu'na alınan ergin kişilerin koruma amacıyla özgürlüğünün kısıtlanmasına ilişkin hükümlerin (Art. 397a-397f ZGB / TMK 432-437) genel gerekçesinde, bu düzenlemenin aynı

\section{Lustenberger, s. 7; BB1 1977 III 17 vd.}

Bkz., Tuor/Schnyder/Rumo-Jungo, s. 511-512; Lustenberger, s. 3.

İsviçre'de 1978 revizyonunda velayet altındaki küçüğün koruma amacıyla özgürlüğünün kısıtlanması da Art. 310 ZGB (Krş., TMK 347) hükmüyle bağlantılı olarak Art. 314a ZGB hükmü ile düzenlenmiştir (Konuya ilişkin olarak bkz., BBl 1977 III 46; Lustenberger, s. 11 vd., 32 vd.). Art. 314a hükmü, Yeni Medeni Kanun'a alınmamıştır. Bu hususun eleştirisi için bkz., Dural, Mustafa/Öğüz, Tufan/Gümüş, Mustafa Alper: Türk Özel Hukuku, Cilt III, Aile Hukuku, İstanbul 2005, s. 681. Gümüş’e göre velayet altındaki küçügün koruma amacıyla özgürlüğünün kısıtlanmasına ilişkin Art. 314a ZGB hükmünün alınmamış olması, bu hususta Türk hukuku bakımından gerçek bir kanun boşluğu yaratmıştır; bu boşluk, Art. 314a ZGB hükmünden yararlanılarak doldurulmalidir (s. 681, 684).

9 Avrupa İnsan Hakları Sözleşmesi, Türkiye tarafından 4 Kasım 1950 tarihinde imzalanmış ve 10.03.1954 tarihli ve 6366 sayılı Kanunla onaylanmıştır (RG.19.03.1954, 8662). Sözleşme'ye değişiklik getiren 11 No.lu Protokol de Türkiye tarafindan 11 Mayıs 1994 tarihinde imzalanmış, 14.05.1997 tarihli ve 4255 sayılı Kanunla onaylanması uygun bulunmuş ve Bakanlar Kurulu'nca 30.05.1997 tarihinde onaylanması kararlaştırılmıştır (RG.20.06.1997, 23025). Sözleşme'nin Türkiye tarafindan onaylanması hususunda ayrıca bkz., Gözübüyük/Gölcüklü, s. 18 vd. 
zamanda Anayasa'nın 19. maddesinin gereği olduğu da ifade edilmiştir ${ }^{10}{ }^{11}$.

III. Vesayet Altındaki Küçüğün Koruma Amacıyla Özgürlüğünün Kısıtlanması Kavramı ve Vasinin Küçüğe Özen Gösterme Yükümü İle İlişkisi

\section{Vesayet Altındaki Küçüğün Koruma Amacıyla Özgürlüğünün Kısıtlanması Kavramı}

Koruma amaciyla özgürlüğün kısıtlanmasında, içinde bulunduğu belirli bir zayıflık hali sebebiyle korunmaya ihtiyaç gösteren kişiye, özgürlüğünün kısıtlanması yoluyla gereken korunmanın sağlanmasına çalış1lır ${ }^{12}$. Burada kişisel özgürlük hakkına, özellikle kişinin hareket özgürlüğüne yönelik bir müdahale vuku bulmaktadır ${ }^{13}$. Bu müdahale, korunması amaçlanan kişinin iradesine karşı veya iradesi bulunmaksızın bir kuruma yerleştirilmesi veya orada alıkonulması suretiyle gerçekleşir ${ }^{14}$.

Vesayet altındaki küçüğün koruma amaciyla özgürlüğünün kısıtlanmasında da küçüğün iradesine karşı veya iradesi bulunmaksızın bir kuruma yerleştirilmesi veya orada alıkonulması söz konusu olmaktadır ${ }^{15}$. Burada vesayet altındaki küçüğün somut halde gösterdiği korunma ihtiyac1, başka şekilde karşılanamadığı için bu yola başvurulmaktadır ${ }^{16}$; küçüğün uygun bir kuruma yerleştirilmesi suretiyle ihtiyaç duyduğu korunmanın sağlanmasına çalışılmaktadır.

Vesayet altındaki küçüğün koruma amacıyla özgürlüğünün kısitlanmasina vesayet organları olarak vesayet makamı ve gecikmesinde

$10 \quad$ Bkz., Kanun'un gerekçesi (Dn.1), s. 22, 144.

11 Yeni Medeni Kanun'da koruma amacıyla özgürlüğün kısıtlanmasıyla ilgili düzenleme çerçevesinde, İsviçre Medeni Kanunu'nun 1978 revizyonuyla değiştirilen ve gecikmesinde sakınca bulunan hallerde vasiye, koruma amacıyla özgürlüğün kısıtlanmasına ilişkin hükümlere göre kısıtlıyı bir kuruma yerleştirme veya orada alıkoyma yetkisi tanıyan Art. 406 hükmü de dikkate alınmıştır (Krş., TMK 447).

12 Bu hususta bkz., BSK ZGB I- Geiser, Art. 397a N 2 vd.; ZK- Spirig, Art. 397a N 7 vd.; Caviezel-Jost, s. 116 vd.; Müller, s. 267 vd., 58 vd.; Tuor/Schnyder/Rumo-Jungo, s. 512 vd.; Schnyder, Bernhard/Murer, Erwin: Kommentar zum schweizerischen Privatrecht, Band II, Das Familienrecht, 3. Abteilung, Die Vormundschaft, 1. Teilband, Systematischer Teil und Kommentar zu den Art. 360-397f ZGB, 1. Lieferung, Systematischer Teil und Kommentar zu den Art. 360-378 ZGB (3. Auflage), Bern 1982, Syst. Teil N 249 vd.; BB1 1977 III 22 vd., 26 vd.; Dural/Öğüz/Gümüş, s. 684 vd.

13 Krş., BSK ZGB I- Geiser, Art. 397a N 12; Caviezel-Jost, s. 331 vd.; Müller, s. 267 vd.; BBl 1977 III 22. Avrupa İnsan Hakları Sözleşmesi'ne göre kişisel özgürlük hakkının kapsamıyla ilgili olarak bkz., Huber, Hans: "Die persönliche Freiheit", SJZ 1973, s. 113 vd., 121.

15 Müller, s. 267 vd., 288, 171-172.

16 BSK ZGB I- Geiser, Art. 405a N 3; Müller, s. 288 vd., 294 vd., 302 vd. 
sakınca bulunan hallerde bizzat vasi karar verir (TMK 446) ${ }^{17}$. Burada vesayete ilişkin bir önlem söz konusu olmaktadır ${ }^{18}$. Bu önlemle, vesayet hukukunun diğer önlemleri gibi zayıfın korunması amaçlanır ${ }^{19}$; küçüğün somut halde ihtiyaç duyduğu korunma ve desteğin sağlanması suretiyle zayıflığının aşılması için çaba gösterilir.

\section{Vasinin Özen Gösterme Yükümü}

Vasi, vesayet altında bulunan kişiye özen göstermekle yükümlüdür ${ }^{20}$. Kişiye özen gösterme yükümü ile vesayet altındaki kişinin kişisel korunma ve destek ihtiyacının karşılanmasına çalışılır ${ }^{21}$. Burada vasinin göstermesi gereken özen, bizzat vesayet altında bulunan kişiye yönelmiştir ve bu bağlamda korunmak istenen hukuki değer, vesayet altındaki kişinin kişi varllı̆ ${ }_{1} d{ }^{22}{ }^{22}$.

Vasinin vesayet altında bulunan kişiye özen gösterme yükümü, küçüklere ilişkin olarak Türk Medeni Kanunu'nun 445. maddesinde düzenlenmiştir. Buna göre vasi, vesayet altındaki küçügün bakımı ve eğitimi için gerekli önlemleri almakla yükümlüdür. Şu halde 445. maddedeki düzenleme uyarınca küçüğe özen yükümünün içeriği, küçüğün bakımının ve eğitiminin sağlanmasından oluşmaktadır ${ }^{23}$. Burada kanunkoyucu, özen yükümünün içeriğiyle ilgili olarak ayrıntılı bir düzenleme yerine, genel bir ifadeyle küçüğün bakımı ve eğitimi açısından belirli bir çerçeve ortaya koymakla yetinmiştir ${ }^{24}$. Kişiye özen yükümünün ifası, kanunun öngördüğü

17 İsviçre hukuku için bkz., BSK ZGB I- Geiser, Art. 405a N 7 vd.; Müller, s. 305 vd.

18 Müller, s. 277-278, 285 vd., 287; Riemer, Hans Michael: Grundriss des Vormundschaftsrechts, 2.Auflage, Bern 1997, § 3 N 12, N 19; BK- Schnyder/Murer, Syst. Teil N 103; ayrıca Dural/Öğ̈̈z/Gümüş, s. 682.

19 Müller, s. 277 vd., 285 vd.; Vesayet hukukunda zayıfın korunması amacına ilişkin olarak BK- Schnyder / Murer, Syst. Teil N 242 vd.; ayrica bkz., Riemer, § 3 N 1-2.

20 Vasinin özen yükümüne ilişkin olarak BK- Schnyder/Murer, Art. 367 N 18 vd.; Langenegger, Ernst: Basler Kommentar zum Schweizerischen Privatrecht (Hrsg., Heinrich Honsell / Nedim Peter Vogt / Thomas Geiser), Zivilgesetzbuch I, Art. 1-456 ZGB, 2.Auflage, Basel 2002, Art. 367 N 2; Affolter, Kurt: Basler Kommentar zum Schweizerischen Privatrecht (Hrsg., Honsell, Heinrich/Vogt, Nedim Peter/Geiser, Thomas), Zivilgesetzbuch I, Art. 1-456 ZGB, 2.Auflage, Basel 2002, Art. 405 N 1, Art. 406 N 1; Riemer, § 4 N 144; Tuor/Schnyder/Rumo-Jungo, s. 524 vd.; Müller, s. 79 vd., 87 vd.; Dural/Öğüz/Gümüş, s. 631 vd.; Öztan, Bilge: Aile Hukuku, 5. Bas1, Ankara 2004, s. 820 vd.; Akıntürk, Turgut: Türk Medeni Hukuku, Yeni Medeni Kanuna Uyarlanmış Aile Hukuku, İkinci Cilt, 6. Bası, İstanbul 2002, s. 514-515.

BK- Schnyder/Murer, Syst. Teil N 35, N 16, N 18; Müller, s. 58.

22 BK- Schnyder/Murer, Syst. Teil, N 18 vd.; Riemer, § 4 N 144; Müller, s. 58, 79 vd., 89; Dural/Öğüz/Gümüş, s. 631.

23 Bu hususta BSK ZGB I- Affolter, Art. 405 N 1; Müller, s. 93 vd.; Dural/Öğüz/Gümüş, s. 632.

24 Krş., Müller, s. 93. 
bu çerçeve içinde vesayet altındaki küçüğe bağlı olarak bireysel gerçekleşir; bu yönde vasi tarafından alınması gerekli görülen önlemler, münferit halin özelliklerine göre farklılık gösterir ${ }^{25}$.

Aslında TMK 445 hükmü, vasinin görevlerini genel olarak belirleyen TMK 403 hükmünü somutlaştıran bir düzenlemedir ${ }^{26}$. Şöyle ki TMK 403 hükmüne göre vasi, vesayet altındaki küçügün veya kısıtlının kişiliği ve malvarlığ 1 ile ilgili bütün menfaatlerini korumakla ve hukuki işlemlerde onu temsil etmekle yükümlüdür. Burada 445. madde, küçüğe gösterilmesi gereken özeni düzenleyerek vasinin, küçüğün kişiliği ile ilgili menfaatlerini koruma yükümünü somutlaştırmaktadır. Bu noktada şu husus da vurgulanmalıdır; vasi, küçüğe özen yükümünü ifa ederken küçüğün bütün menfaatlerini göz önünde bulunduracaktır ve küçüğe özen yükümünün gerekli kıldığ 1 hukuki fiilleri küçüğü temsil etmek suretiyle gerçekleştirecektir ${ }^{27}$.

Küçüğe gereken özenin gösterilmesinde vasi, esasen ana babayı ikame etmektedir $^{28}$. Şöyle ki küçüğün eksik doğal ve hukuki erginliği sebebiyle desteğe ve korunmaya ihtiyacı vardır. Bu bağlamda küçüğe, bağımsızlığını kazanıp kendi sorumluluğunu taşıyabilecek olgunluğa erişinceye kadar ihtiyaç duyduğu destek ve korunmanın sağlanması, doğal olarak, ahlaken ve öncelikle ana babanın görevidir ${ }^{29}$. Nitekim küçük ${ }^{30}$, ilke olarak erginliğini elde edinceye kadar ana babanın velayeti altında bulunur. Ancak küçüğün velayet altında bulunmadığı halde, küçüğe vasi atanır (Bkz., TMK 404/I) ${ }^{31}$ ve vasi, ana babanın yerine geçerek küçüğün sorumluluğunu üstlenir.

25 Müller, s. 94 vd., 107 vd.

26 BSK ZGB I- Affolter, Art. 405 N 1; krş., Müller, s. 89-90; BK- Schnyder/Murer, Art. 367 N 19; Dural/Öğüz/Gümüş, s. 631.

27 Müller, s. 89-90, 80 vd.; BSK ZGB I- Affolter, Art. 405 N 2; ayrıca bkz., BKSchnyder/Murer, Syst. Teil N 34, N 19-20; Egger, A.: Kommentar zum Schweizerischen Zivilgesetzbuch, II. Band, Das Familienrecht, 3. Abteilung, Die Vormundschaft, Art. 360-456, 2. Auflage, Zürich 1948, Art. 405 N 14; Kaufmann, Joseph: Kommentar zum Schweizerischen Zivilgesetzbuch, Band II, Familienrecht, 3. Abteilung, Die Vormundschaft, Art. 360-456, 2. Auflage, Bern 1924, Vorbemerkungen zu Art. 405 / 406 N 3 vd.

28 BSK ZGB I- Affolter, Art. 405 N 4; Müller, s. 63 vd., 87 vd., 101, 118 vd.; Tuor/Schnyder/Rumo-Jungo, s. 524; Riemer, § 4 N 145.

29 Krş., Hegnauer, Cyril: Grundriss des Kindesrechts und des übrigen Verwandtschaftsrechts, 5. Auflage, Bern 1999, N 1.05; Müller, s. 101, 51 vd.

30 Küçük, Türk Medeni Kanunu'na göre, kanuni erginlik yaşı olan onsekiz yaşını henüz doldurmamış ve bunun yanı sıra halihazırda evlenme yoluyla ya da hakimin hükmü ile erginliğini elde etmemiş bulunan kişiyi ifade eder (Bkz., TMK 11, 12).

31 Küçüğün velayet altında bulunmaması, çeşitli sebeplerden kaynaklanabilir; bu bağlamda mesela küçüğün ana babası hayatta olmayabilir veya ana babanın gaipliğine hükmedilmiş olabilir ya da ana babanın velayet hakkı kaldırılmış olabilir. Bu hususta bkz., Öztan, s. 757; BK- Schnyder/Murer, Art. 368 N 25, N 30 vd.; Müller, s. 62. 
Özen yükümünün ifasında vasi, ilke olarak ana babanın yetkilerine sahiptir; ancak ana babadan farklı olarak vasi, geniş ölçüde vesayet dairelerinin gözetim ve denetimine tabidir; keza bazı işlemlerin yapılabilmesi, vesayet dairelerinin iznini gerektirir (Bkz., TMK 445/II) ${ }^{32}$. Bununla birlikte vesayet dairelerinin müdahale yetkilerinin dışında vasi, faaliyetlerini bağımsız yürütür ${ }^{33}$. Bu yönde vasi, küçüğün bakımı ve eğitimi için hangi önlemlerin alınması gerektiğine bizzat karar verir. Bu bağlamda vasi, takdir yetkisini kullanırken ilke olarak üçüncü kişilerin tavsiyelerini almakla yükümlü değildir ${ }^{34}$. Öte yandan vasi, harekete geçmek için prensipte vesayet dairelerinin talimatların da bekleyemez ${ }^{35}$; kendi takdir yetkisini kullanarak karar vermelidir. Ancak vasi, özen yükümünü yerine getirirken ve bu esnada takdir yetkisini kullanırken bazı esaslara göre hareket etmelidir ${ }^{36}$ :

Vasi, küçüğe özen gösterme yükümünü amacına yönelik olarak yerine getirmelidir. Kü̧̈üğe gereken özenin gösterilmesinden maksat, küçüğün kişisel korunma ve desteğe ihtiyaç gösteren zayıflık halinin, küçüğün doğal ve hukuki erginliğini elde edinceye kadarki gelişim sürecinde her aşamada uygun önlemlerle dengelenmesi ve küçüğün erginliğe erişmekle birlikte kendi sorumluluğunu taşıyan bir insan olarak sosyal entegrasyonunun sağlanmasıdır ${ }^{37}$. Vasi, özen yükümünün gerekli kıldığı bütün faaliyetleri, küçügün menfaatine gerçekleştirmelidir ve küçügün menfaatinin söz konusu olduğu her yerde esasen küçüğün yararını göz önünde bulundurmalıdır ${ }^{38}$.

Vesayet altındaki küçüğün yararı, özen yükümünün ifasında yönlendirici ve sınırlayıcı ilkedir ${ }^{39}$; buna göre her somut durumda küçüğün zayıflığının optimal dengelenmesi ve küçüğün optimal gelişimi için gerekli şartlar teşekkül ettirilmelidir. Nitekim vasinin çeşitli imkanlar arasında küçük için en uygun alternatifi seçme yükümü, vesayetin küçügün yararına yönelmiş bulunmasından kaynaklanmaktadır ${ }^{40}$. Bu yönde vasi, küçük için

32 Bu hususta bkz. ve krş., Müller, s. 72, 73 vd., 112 vd., 120; Tuor/Schnyder/RumoJungo, s. 524; BSK ZGB I- Affolter, Art. 405 N 21; Dural/Öğüz/Gümüş, s. 632; Öztan, s. 820-821.

Müller, s. $72 \mathrm{vd} ., 112 \mathrm{vd}$

Müller, s. 113. Doktrinde küçüğün yararına olduğu takdirde ana babanın görüş ve isteklerinin imkan ölçüsünde vasi tarafindan dikkate alınması yönünde bkz., Müller, s. 117; BK- Kaufmann, Art. 405 N 16, N 7; ayrica krş., Öztan, s. 820; Dural/Öğ̈̈̈z/Gümüş, s. 632.

35 Müller, s. 113; BK- Kaufmann, Art. 405 N 6.

36 Bu hususta bkz. ve krş., Müller, s. 94, 103 vd.; BSK ZGB I- Affolter, Art. 405 N 13 vd.

37 Müller, s. 88-89, 96, 100.

38 Müller, s. 104 vd., 106, 65.

39 Müller, s. 104 vd., 106; BSK ZGB I- Affolter, Art. 405 N 14; ayrıca Hegnauer, N 26.04a.

40 Müller, s. 104. 
gereken önlemleri, her münferit halde küçügün yararını yorumlamak ve somutlaştırmak suretiyle tespit eder ve uygular.

Küçüğün yararına yönelme, küçüğün kişiliğini dikkate alma anlamına gelir $^{41}$. Gerçekten de küçüğün yararı, küçüğün ayrı bir kişilik olarak idrakiyle birlikte, küçüğün kişiliğine saygı gösterilmesini gerektirir; bu noktada küçüğün kişiliğinin korunması ve geliştirilmesi özel önem taşır. Bu yönde vasi, küçüğe hayatını yönlendirmede olabildiğince kendi sorumluluğunu üstlenme imkanı tanımalıdır ${ }^{42}$. Esasen burada vasiye özen yükümünün ifasında ana babanın yetkilerini tanıan TMK 445/II çerçevesinde velayetin içeriğine ilişkin hükümlere (TMK 339 vd.) yapılan atıf bağlamında çocuğun kişiliğine saygı gösterilmesi ilkesini somutlaştıran TMK 339/III hükmünün vesayet altındaki küçük bakımından da uygulanması gerekir ${ }^{43}$. Buna göre vasi, olgunluğu ölçüsünde küçüğe hayatını düzenleme imkanı tanımakla yükümlüdür. Öte yandan vasi, önemli konularda olabildiğince küçüğün düşüncesini de göz önünde tutmalıdır. TMK 339/III'de yer verilen küçügün görüşünü alma yükümü, vesayete ilişkin hükümlerde vasinin vesayet altındaki kişiyi temsil görevi çerçevesinde de düzenlenmiş bulunmaktadır (Bkz., TMK 450/I) ${ }^{44}$.

Diğer taraftan küçük, yaşı ve olgunluğu sebebiyle hayatını kendi iradesine göre ve makul surette düzenleyebilecek durumda bulunduğu takdirde, kendi başına hareket edebilirr ${ }^{45}$. Burada vasi tarafından aşılması gereken bir zayıflık hali yoktur; bu noktada küçüğün iradesi belirleyici rol oynar $^{46}$. Özellikle kişiye sıkı sıkıya bağlı hakların kullanılmasında (TMK 16/I) ve küçüğün fiil ehliyetinin genişletildiği hallerde (TMK 453, 455) durum böyledir ${ }^{47}$.

Vasi, özen yükümünü yerine getirirken ölçülülük ilkesinin gerekleriyle uyumlu olarak küçüğün somut korunma ihtiyacına uygun önlemleri almalıdır ${ }^{48}$. Bu bağlamda alınan önlemler, küçüğün somut zayıflık

41 Krş., Tschümperlin, Urs: Die elterliche Gewalt in Bezug auf die Person des Kindes (Art. 301 bis 303 ZGB), Freiburg 1989, s. 82, 95 vd.; BSK ZGB I- Affolter, Art. $405 \mathrm{~N}$ 14; Müller, s. 104 vd., 106, 111.

42 Krş., Müller, s. 106, 115 vd.; BSK ZGB I- Affolter, Art. 405 N 16.

43 Krş., Müller, s. 121-122, 111, 95; BSK ZGB I- Affolter, Art. 405 N 4.

44 İsviçre hukukundaki durum için bkz., BSK ZGB I- Affolter, Art. 405 N 14; Leuba, Audrey: Basler Kommentar zum Schweizerischen Privatrecht (Hrsg., Honsell, Heinrich/Vogt, Nedim Peter/Geiser, Thomas), Zivilgesetzbuch I, Art. 1-456 ZGB, 2. Auflage, Basel 2002, Art. 409 N 3a.

$45 \mathrm{Bu}$ hususta Müller, s. 115 vd.; BSK ZGB I- Affolter, Art. $405 \mathrm{~N}$ 16; Tuor/Schnyder/Rumo-Jungo, s. 527 vd.

46 Krş., Müller, s. 115, 104 vd., 106; BSK ZGB I- Affolter, Art. 405 N 16.

47 Krş., Müller, s. 115; Tuor/Schnyder/Rumo-Jungo, s. 528 vd.

48 Müller, s. 59, 102 vd., 107 vd., 134-135; Riemer, § 4 N 147; ayrıca BK- 
durumunu dengeleme amacı bakımından elverişli, zorunlu ve makul (oranlı) olmalıdır; sözü edilen önlemleri vasi, küçüğün yaşını, kişiliğini, aile ve çevre şartlarını göz önünde bulundurarak içerik, kapsam, süre vb. yönünden münferit halin özelliklerine göre tespit etmelidirr ${ }^{49}$. Öte yandan vasi, somut halde fiilen gerçekleştirilebilir önlemi almalıdır ${ }^{50}$.

Özen yükümüne ilişkin 445. maddede, yukarıda da ifade edildiği gibi, vasinin, küçüğün bakımı ve eğitimi için gereken önlemleri alacağ 1 hususu hükme bağlanmıştır. Bu çerçevede vasi, küçüğün beslenme, giyim, barınma ve sağlıkla ilgili temel ihtiyaçlarını ve bunun yanı sıra küçüğün sosyal ve kültürel ihtiyaçlarını, özellikle küçüğün yetenek ve eğilimlerine uygun eğitim talebini karşılamakla yükümlüdür ${ }^{51}$. Burada vasi, söz konusu ihtiyaçları karşılamak üzere, bir yandan küçüğün bakımının ve eğitiminin doğrudan sağlanmasına yönelik önlemleri almalıdır (mesela küçüğün bir aile yanına veya bir kuruma yerleştirilmesi ya da hastanede tedavi ettirilmesi gibi); diğer yandan da bu ihtiyaçların temini için gerekli masrafların karşılanmasına yönelik önlemlere başvurmalıdır (mesela küçüğün ana babasından nafaka talebinde bulunulması veya Devletten yardım istenilmesi gibi) $^{52}$.

Vasi, küçüğün bakımı ve eğitimi ile ilgili faaliyetleri bizzat gerçekleştirmekle yükümlü olmadığ 1 gibi, bakım ve eğitim için gerekli masrafları da bizzat karşılamakla yükümlü değildir ${ }^{53}$. TMK 445. madde hükmü çerçevesinde vasinin yükümü, sadece gereken önlemlerin alınmasından oluşur; bununla birlikte vasinin küçüğün bakımı ve eğitimiyle bizzat ilgilenmesi de mümkündür ${ }^{54}$. Vasi, küçüğün bakımı ve eğitimiyle ilgili olarak üçüncü kişiyi görevlendirdiği takdirde, üçüncü kişinin seçiminde gerekli özeni göstermelidir; keza vasi, bu halde üçüncü kişiye gereken biçimde talimat verilmesinden ve üçüncü kişinin kontrolünden de sorumlu olur ${ }^{55}$.

Schnyder/Murer, Syst. Teil N 275 vd.; Caviezel-Jost, s. 323 vd.

49 Müller, s. 107 vd., 97; ayrica BSK ZGB I- Affolter, Art. 405 N 13; Tuor/Schnyder/Rumo-Jungo, s. 524.

50 Müller, s. 109.

51 Bu hususta Müller, s. 128 vd., 130, 141 vd., 169 vd., 202 vd., 221 vd., 238 vd.; BSK ZGB I- Affolter, Art. 405 N 23 vd.; Tuor/Schnyder/Rumo-Jungo, s. 524 vd.; Riemer, $\S 4$ N 144; Dural/Öğüz/Gümüş, s. 631-632; Öztan, s. 820 vd.; Akıntürk, s. 514 vd.

52 Bkz., dn.51.

53 Bu hususta bkz. ve krş., Müller, s. 113-114, 128, 204; BSK ZGB I- Affolter, Art. 405 N 26 vd., N 33 vd.; Tuor/Schnyder/Rumo-Jungo, s. 524 vd.; Dural/Öğüz/Gümüş, s. 632; Öztan, s. 821.

$54 \quad$ Krş., Müller, s. 113, dn.84, s. 128; BK- Kaufmann, Art. 405 N 11.

55 Müller, s. 114; ZK- Egger, Art. 405 N 21; BK- Kaufmann, Art. 405 N 11, N 13. 


\section{Vesayet Altındaki Küçüğün Koruma Amacıyla Özgürlüğünün Kısıtlanmasının Vasinin Özen Gösterme Yükümü İle İlişskisi}

Doktrinde vesayet altındaki küçüğün koruma amacıyla özgürlüğünün kısıtlanmasının, vasinin küçüğe göstermesi gereken özenle sıkı bir ilişki içinde bulunduğu ifade edilmektedir ${ }^{56}$. Şöyle ki gerek koruma amaciyla özgürlüğün kısıtlanması gerek özen yükümü ile amaçlanan, küçüğün ihtiyaç duyduğu korunma ve desteğin sağlanmasıdır ${ }^{57}$. Bu suretle küçüğün içinde bulunduğu zayıflık halinin dengelenmesine çalışılır. Burada gaye, her halükarda küçügün her yönüyle optimal gelișiminin temin edilmesi ve böylece küçüğün yararının gerçekleştirilmesidir. Koruma amacıyla özgürlügün kısıtlanmasında, daha önce de belirtildiği gibi, küçügün korunma ve destek ihtiyac1, onun uygun bir kuruma yerleştirilmesi suretiyle sağlanmaya çalışılır ve esasen somut halde küçüğün yararının korunması, başka bir biçimde mümkün olmadığı içindir ki koruma amacıyla özgürlüğün kısıtlanması yoluna başvurulmaktadır ${ }^{58}$. Burada koruma amaciyla özgürlüğün kısıtlanmasının, özen yükümünün gereklerinin yerine getirilebilmesi açısından başvurulabilecek etkili tek ve son çare (ultima ratio) olarak ortaya çıktığını ifade etmek mümkündür ${ }^{59}$.

Bu noktada koruma amacıyla özgürlüğün kısıtlanması, vasinin özen yükümünü tamamlayıcı bir fonksiyon göstermektedir ${ }^{60}$. Bu itibarla vesayet altındaki küçüğün koruma amacıyla özgürlüğünün kısıtlanması anlamında bir kuruma yerleştirilmesinin şartları belirlenirken, vasinin özen yükümü ile olan bu fonksiyonel bağlantının göz önünde tutulması gerekir ${ }^{61}$. Aslında vesayet altındaki küçüğün koruma amacıyla özgürlüğünün kısıtlanmasına ilişkin TMK 446 hükmünün Kanun'daki sistematik yeri de sözü edilen fonksiyonel bağlantıya işaret etmektedir ${ }^{62}$. Gerçekten de TMK 446 hükmü, daha önce de değinildiği üzere, vasinin küçüğe özen yükümünü genel olarak düzenleyen TMK 445 hükmünü takip etmektedir. Öte yandan 446. maddede gecikmesinde sakınca bulunan hallerin dışında küçüğün koruma amacıyla bir

56 Müller, s. 285 vd., 294; krş., BSK ZGB I- Geiser, Art. 405a N 3; Dural/Öğüz/Gümüş, s. 633.

57 Müller, s. 287.

58 Bu hususta bkz. ve krş., Müller, s. 267 vd., 288 vd., 295; BSK ZGB I- Geiser, Art. 405a N 3; Dural/Öğüz/Gümüşs, s. 633.

59 Krş., Müller, s. 284-285, 295, 297. Koruma amacıyla özgürlüğün kısıtlanmasına ultima ratio olarak başvurulması hususunda bkz., ZK- Spirig, Art. 397a N 260; BSK ZGB IGeiser, Art. 397a N 12 vd.; Tuor/Schnyder/Rumo-Jungo, s. 513; Caviezel-Jost, s. 331 vd.; Suhr Brunner, s. 97 vd.; BBl 1977 III 27.

60 Krş., Müller, s. 286 vd.

61 Müller, s. 292 vd., 294; krş., BSK ZGB I- Geiser, Art. 405a N 3; Dural/Öğüz/Gümüş, s. 633.

62 Krş., Müller, s. 286, 277. 
kuruma yerleştirilmesine vasinin başvurusu üzerine vesayet makamının karar vereceği hükme bağlanmıştır. Şu halde şartlar gerektirdiği takdirde, normalde küçügün kuruma yerleştirilmesine yönelik başvuruyu vasi yapmak zorundadır. Açıktır ki burada vasi tarafından küçüğün menfaatine gerçekleştirilen küçüğe yönelik bir özen fiili söz konusu olmaktadır ${ }^{63}$. Ayrıca gecikmesinde sakınca bulunan hallerde vasi de küçüğün kuruma yerleştirilmesine bizzat karar verebilecektir.

Belirtilmesi gereken bir diğer husus da şudur; gecikmesinde sakınca bulunan haller dışında vesayet altındaki küçüğün koruma amacıyla kuruma yerleştirilmesi, vesayet makamının yetkisindedir. Buna göre burada vesayet makamının katılımı, vasinin vesayeti yürütürken ve özen yükümünü yerine getirirken prensipte sahip olduğu bağımsızlığa bir müdahale teşkil eder ${ }^{64}$.

IV. Vesayet Altındaki Küçüğün Koruma Amacıyla Özgürlüğünün Kisitlanmasının Şartları

\section{Genel Olarak}

Vasi, vesayeti altında bulunan küçüğün sorumluluğunu taşı;; bu durum, küçüğün hayatının her yönüyle düzenlenmesini ve küçüğün menfaatine yönelik özen fiillerini gerektirir. Vasinin küçüğe göstermesi gereken özen çerçevesine küçügün uygun bir biçimde yerleştirilmesi de dahildir $^{65}$. Diğer bir ifadeyle küçüğe, optimal gelişimi için uygun şartların bulunduğu bir yer temin edilmelidir. Bu bağlamda küçüğün bir aile yanına veya yurt vb. bir kuruma yerleştirilmesi söz konusu olabilir ${ }^{66}$. İfade etmek gerekir ki vasinin yerleştirme yetkisi, esasen onun küçüğün kalacağ 1 yeri belirleme yetkisinden kaynaklanmaktadır (TMK 445/II ve 339/IV) ${ }^{67}$.

Koruma amacıyla özgürlüğün kısıtlanması, vesayet altındaki küçük bakımından kuruma yerleştirilmenin özel bir halini oluşturur ${ }^{68}$. Şöyle ki burada küçüğün kuruma yerleştirilmesi, küçügün iradesine karşı veya iradesi bulunmaksızın, kamu gücüne dayanılarak zorla gerçekleşir. Öte yandan küçüğün yerleştirildiği kurum, koruma amacı açısından elverişli bir kurum niteliğini taşımalıdır ve söz konusu kurumda küçüğün özgürlüğü, ortalama bir aile çevresinde bulunan yaşıtlarınınkine göre daha çok kısıtlanmış olmalıdır ${ }^{69}$. Bu noktada küçüğün özgürlüğüne yönelik ağır bir müdahale

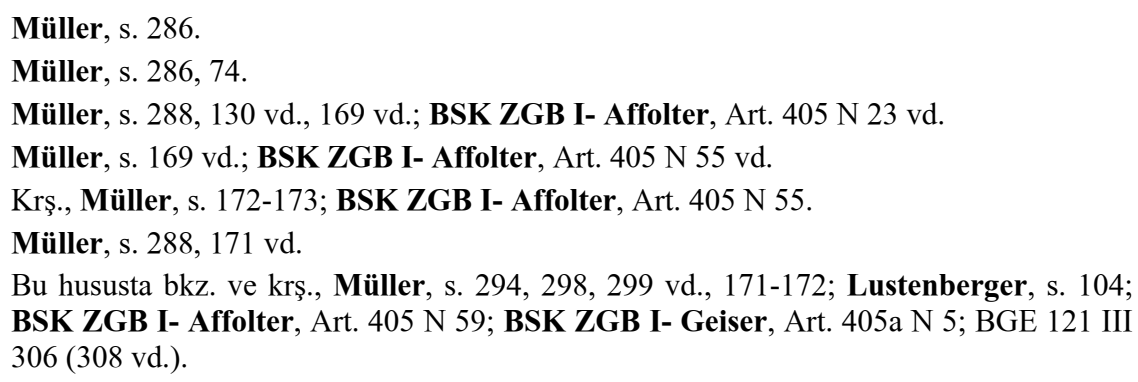


olarak küçüğün koruma amaciyla bir kuruma yerleştirilmesinin belirli şartları gerektirdiği açıktır ${ }^{70}$.

Vesayet altındaki küçüğün koruma amacıyla bir kuruma yerleştirilebileceğini öngören TMK 446 hükmünde, bunun hangi şartlar çerçevesinde mümkün olabileceği belirtilmemiştir ${ }^{71}$. Diğer bir ifadeyle 446 . maddede vesayet altındaki küçüğün koruma amaciyla özgürlüğünün kısıtlanmasının şartları yer almamaktadır. TMK 446 hükmüne kaynak teşkil eden İsviçre Medeni Kanunu'nun Art. 405a hükmünde de vesayet altındaki küçügün koruma amacıyla özgürlügünün kısıtlanması anlamında bir kuruma yerleştirilmesinin şartlarına yer verilmemiştir ${ }^{72}{ }^{73}$.

Vesayet altındaki küçüğün koruma amaciyla özgürlüğünün kısıtlanmasına ilişkin şartların belirlenmesi bakımından İsviçre doktrininde özellikle vesayet altındaki küçügün koruma amacıyla özgürlügünün kısıtlanması ile vasinin özen gösterme yükümü arasındaki fonksiyonel bağlantının göz önünde bulundurulması gereğine işaret edilmektedir ${ }^{74}$. Bu bağlamda, daha önce de ifade edildiği üzere, somut halde küçüğün ihtiyaç duyduğu korunma ve desteğin sağlanması, başka bir biçimde mümkün olmadığ1 için son çare (ultima ratio) olarak koruma amacıyla özgürlüğün kısitlanması yoluna gidilmektedir ${ }^{75}$. Müller'e göre bu hususta Avrupa İnsan Hakları Sözleşmesi'nin küçüklerde özgürlüğün kısıtlanmasıyla ilgili hükmü (m. 5/I-d) de dikkate alınmalıdır ${ }^{76}$. Anılan hüküm, bir küçüğün gözetim

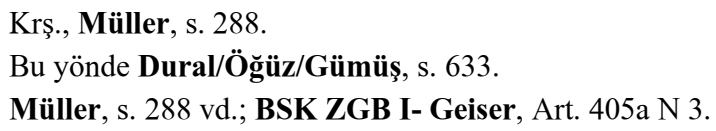

Bu noktada ifade etmek gerekir ki Art. 405a hükmünün ikinci fikrasında -ilk fikradaki yetkiye ilişkin doğrudan düzenlemenin dışında- vesayet altındaki küçüğün koruma amacıyla özgürlüğünün kısıtlanmasında yetki, itiraz ve usulle ilgili konularda erginlerin veya kısıtlıların koruma amacıyla özgürlüklerinin kısıtlanmasına ilişkin hükümlere (Art. 397b-f) atıfta bulunulmuştur; buna karşılık anılan fikra hükmünde erginlerde veya kısıtlılarda koruma amacıyla özgürlüğün kısıtlanmasının șartlarına ilișkin Art. 397a hükmüne atıf yapılmamıştır. TMK 446 hükmündeki düzenleme de bu yöndedir. Buna göre doktrinde Art. 397a ZGB / TMK 432 hükmündeki şartların vesayet altındaki küçüğün Art. 405a ZGB / TMK 446 uyarınca kuruma yerleştirilmesi bakımından kıyasen uygulanamayacağı kabul edilmektedir. Ancak vesayet altındaki küçüğün koruma amacıyla özgürlüğünün kısıtlanmasında da ölçülülük ilkesi çerçevesinde küçüğün kişisel korunmasının başka şekilde sağlanamaması gerekir ve küçüğün yerleştirileceği kurumun, koruma amacı bakımından elverişli (uygun) bir kurum olması gerekir. Bu hususta bkz. ve krş., Müller, s. 291, 294 vd.; BSK ZGB I- Geiser, Art. 405a N 3; Türk hukukunda Dural/Öğüz/Gümüş, s. 633.

74 Krş., Müller, s. 292 vd.; BSK ZGB I- Geiser, Art. 405a N 3; Türk hukukunda bu hususta bkz., Dural/Öğüz/Gümüş, s. 633.

75 Bu hususta yukarıda "Vesayet Altındaki Küçüğün Koruma Amacıyla Özgürlüğünün Kısıtlanmasının Vasinin Özen Gösterme Yükümü İle İlişkisi” başlığı altında yaptığımız açıklamalara bkz.

76 Müller, s. 289, 292 vd., 296 vd. 
altında eğitimi amacıyla veya yetkili merci önüne çıkarılmak üzere usulüne uygun olarak tutulması hallerine ilişkindir ${ }^{77}$. Sözü edilen hallerde küçügün özgürlüğünün kısıtlanması, hukuken uygun ve Avrupa İnsan Hakları Sözleşmesi ile bağdaşır nitelikte sayılmaktadır ${ }^{78}$.

Koruma amaciyla özgürlüğün kısıtlanması bakımından özellikle küçügün gözetim altında eğitimi için usulüne uygun olarak tutulması hali üzerinde durulmaktadır. Nitekim İsviçre kanunkoyucusuna göre küçüğün bir kuruma yerleştirilmesi için onun gözetim altında eğitiminin gerekli görülmesi yeterlidir ${ }^{79}$. İsviçre doktrininde de bu yönde ve Avrupa İnsan Hakları Sözleşmesi'ne uygun yorumla küçüğün gözetim altında eğitiminin gerekliliği, onun koruma amacıyla özgürlüğünün kısıtlanması anlamında bir kuruma yerleștirilmesinde göz önünde bulundurulan bir husustur ${ }^{80} . \mathrm{Bu}$ hususun Avrupa İnsan Hakları Sözleşmesi'yle birlikte Anayasa'nın 19. maddesi çerçevesinde Türk hukuku bakımından da göz önünde bulundurulması gerektiği kanısındayız. Belirtilmelidir ki küçüğün gözetim altında eğitiminin gerekliliği de konumuz itibarıyla vesayet altındaki küçügün kuruma yerleştirilmesinin şartlarının, esasen vasi tarafından küçüğe gösterilmesi gereken özenle ilişkili olduğunu ortaya koymaktadır ${ }^{81}$. Şöyle ki daha önce de ifade edildiği gibi, vasi, özen yükümü uyarınca küçüğün bakımını ve eğitimini sağlamalıdır. Küçüğün gözetim altında eğitiminde ise, küçügün somut haldeki korunma ve destek ihtiyacının karşılanmasına yönelik bakım ve eğitimin, buna elverişli bir kurumda, kurum düzeni içinde sağlanması söz konusu olmaktadır ${ }^{82}$.

Şu halde vesayet altındaki küçügün koruma amaciyla özgürlüğünün kısıtlanmasının şartları, vasi tarafından küçüğe gösterilmesi gereken özenle bağlantılı olarak yukarıda yapılan açılamalara göre şöyle ifade edilebilir: Vesayet altındaki küçügün koruma amaciyla özgürlügünün kısıtlanması anlamında bir kuruma yerleştirilebilmesi için kişisel korunmasının somut halde başka şekilde sağlanamaması gerekii ${ }^{83}$. Bu yönde küçüğün kuruma yerleştirilmesi, onun gözetim altında eğitimi amacına yönelik olmalıdır ${ }^{84}$;

77 Avrupa İnsan Hakları Sözleşmesi’nin m.5/I-d hükmüne ilişkin olarak bkz., Gözübüyük/Gölcüklü, s. 233, 448-449; Schubarth, Martin: "Die Artikel 5 und 6 der Konvention, insbesondere im Hinblick auf das schweizerische Strafprozeßrecht", ZSR 1975, s. 476; Müller, s. 273 vd.; ayrıca Lustenberger, s. 37, 38 vd. Müller, s. 273-274; Lustenberger, s. 38; Schubarth, s. 476.

79 BB1 1977 III 47.

80 Müller, s. 296-297. Velayet altındaki küçük bakımından bkz. ve krş., Lustenberger, s. 37 vd.; Tuor/Schnyder/Rumo-Jungo, s. 519, 452-453; BB1 1977 III 46; ayrica Schubarth, s. 476.

81 Krş., Müller, s. 292 vd., 296-297.

82 Krş., Müller, s. 297; Lustenberger, s. 38; ayrıca bkz., Gözübüyük/Gölcüklü, s. 233.

83 BSK ZGB I- Geiser, Art. 405a N 3; Dural/Öğüz/Gümüş, s. 633; krş., Müller, s. 294 vd.

84 Krş., Müller, s. 296-297. 
diğer bir ifadeyle küçüğün gözetim altında eğitiminin gerekliliği söz konusu olmalıdır. Doktrinde bu noktada küçüğün yerleştirilebileceği ve somut haldeki korunma ihtiyacının karş1lanabileceği uygun bir kurumun bulunması gereğine de işaret edilmektedir ${ }^{85}$. Buna göre uygun bir kurumun bulunmas1 da koruma amacıyla özgürlügün kısıtlanması için aranan şartlardan biridir. Aşağıda bu şartlar üzerinde durulacaktır. Ancak daha önce vurgulanması gereken husus şudur ki küçüğün koruma amaciyla özgürlüğünün kısıtlanması anlamında bir kuruma yerleştirilmesi, vesayete ilişkin bir önlem olarak her aşamada ölçülülük ilkesine uygun bir biçimde gerçekleştirilmelidir $^{86}$.

\section{Vesayet Altındaki Küçüğün Kişisel Korunmasının Başka Şekilde Sağlanamaması}

Koruma amaciyla özgürlüğün kısıtlanması anlamında bir kuruma yerleştirilebilmesi için vesayet altında bulunan küçüğün kişisel korunmasının başka şekilde sağlanamaması gerekir ${ }^{87}$. Burada küçük, somut halde kuruma yerleştirilmesini gerekli kılan bir korunma ihtiyacı içerisinde bulunmalıdır ve küçügün sözü edilen korunma ihtiyacı başka şekilde karşılanamamalıdır. Esasen bu noktada vesayet hukukuna ilişkin bir önlem olarak koruma amacıyla özgürlüğün kısıtlanması bakımından ölçülülük ilkesi açı ifadesini bulmaktadır $^{88}$. Buna göre koruma amacıyla özgürlüğün kısıtlanması, küçüğün somut halde ihtiyaç duyduğu korunma ve desteğin sağlanmasi açısından elverişli ve zorunlu bir önlem niteliğini taşımalıdır.

Geiser'e göre küçüğün kişisel korunmasının başka şekilde sağlanamamasından ne anlaşılması gerektiği ve küçüğün neden belirli bir kişisel korunmaya ihtiyaç gösterdiği hususu, çocuk hukukuna özgü bir bakışla değerlendirilir ${ }^{89}$; buna göre burada çocuk için bir tehlike durumu söz konusu olmalıdır.

Müller, küçüğün somut halde özgürlüğünün kısıtlanarak kuruma yerleştirilmesini gerektiren korunma ihtiyacını, özel korunma ihtiyacı olarak şu şekilde izah etmektedir ${ }^{90}$ : Anılan yazara göre normalde vasinin, özen

85 Krş., Müller, s. 298 vd.

86 Krş., Müller, s. 134, 294, 302. Koruma amacıyla özgürlüğün kısıtlanmasında ölçülülük ilkesinin işlevine ilişkin olarak bkz., Caviezel-Jost, s. 331 vd.; Tuor/Schnyder/RumoJungo, s. 513; BSK ZGB I- Geiser, Art. 397a N 12 vd.; ZK- Spirig, Art. 397a N 257 $\mathrm{vd}$.

87 Krş., BSK ZGB I- Geiser, Art. 405a N 3; Dural/Öğüz/Gümüş, s. 633.

88 Bu hususta krş., Caviezel-Jost, s. 331 vd.; Tuor/Schnyder/Rumo-Jungo, s. 513; Öztan, s. 806-807.

89 Krş., BSK ZGB I- Geiser, Art. 405a N 3; velayet altındaki küçük bakımından Breitschmid, Peter: Basler Kommentar zum Schweizerischen Privatrecht (Hrsg., Honsell, Heinrich/Vogt, Nedim Peter/Geiser, Thomas), Zivilgesetzbuch I, Art. 1- 456 ZGB, 2. Auflage, Basel 2002, Art. 314 / 314a, N 8.

90 Müller, s. 294 vd. 
yükümünü gereği gibi ifa etmesi halinde alınan önlemler, küçüğün eksik doğal ve hukuki erginliği sebebiyle ihtiyaç duyduğu korunma ve desteğin sağlanması ve böylece küçügün içinde bulunduğu zayıflık halinin dengelenerek küçüğün yararının gerçekleştirilmesi bakımından yeterli olmalıdır; ancak burada vasinin sözü edilen önlemleri yetersiz kalıyorsa ve küçügün yararının temin edilmesi için sadece küçüğün özgürlüğünün kısıtlanması tek çare olarak görülüyorsa, somut halde küçüğün bunu haklı kılan özel bir korunma ihtiyacı içinde bulunması gerekir. Müller'e göre küçüğün zayıflığının, hastalık, daha önceki eğitim hataları, ağır ihmal gibi belirli sebeplerden dolayı küçügün gelişimini ve bu suretle yararını tehlikeye düşüren bir dereceye erişmiş bulunduğu hallerde, durum böyledir. Burada küçük için gerekli korunma ve desteğin sağlanabilmesi ve bu suretle küçüğün yararına yönelik tehlikenin bertaraf edilebilmesi için küçüğün özgürlüğünün kısitlanması anlamında uygun bir kuruma yerleştirilmesi yönüne gidilir.

Kanımızca koruma amacıyla özgürlügün kısıtlanması anlamında bir kuruma yerleştirilebilmesi için küçüğün eksik doğal ve hukuki erginliği sebebiyle içinde bulunduğu zayıflık halinin diğer bazı (hastalık, eğitim hataları vb.) sebeplerin de eklenmesiyle onun yararını tehlikeye düşüren bir dereceye erişmesi şart değildir. Küȩüğün zayıflığının bu derecede ağırlaşmadığı hallerde de koruma amaciyla özgürlüğün kısıtlanması söz konusu olabilir. Bu hususta küçüğün vesayet altında bulunması göz önünde tutulmalıdır. Şöyle ki vasi, vesayeti altındaki küçüğün sorumluluğunu her yönüyle üstlense de küçüğü yanına alarak onun bakımı ve eğitimi ile bizzat ilgilenmekle yükümlü değildir; buna karşılık vasi, daha önce de ifade edildiği gibi, küçüğe, optimal gelişimi için uygun şartların bulunduğu bir yer temin etmelidir ${ }^{91}$; bu bağlamda vasi, küçüğü bir aile yanına veya kuruma yerleştirebilir. Buna göre somut halde vesayet altındaki küçügün ihtiyaç duyduğu korunmanın sağlanabilmesi ve bu yönde uygun bakım ve eğitimle küçügün yararının gerçekleştirilebilmesi için gerekli şartların sadece belirli bir kurum bünyesinde teşekkül ettirilmesi söz konusu olabilir. Bu durumda küçüğün kişisel korunmasının sağlanması açısından sözü edilen kuruma yerleştirilmesi gerekir; zira aksi takdirde küçüğün yararı tehlikeye düşecektir. Böyle bir halde küçüğün yerleştirileceği kurum, daha önce de ifade edildiği gibi, küçügün özgürlügünü ortalama bir aile çevresinde bulunan yaşıtlarınınkine göre daha çok kısıtlayan bir kurum niteliğindeyse ve küçüğün bu kuruma yerleştirilmesi, onun iradesine karş1 veya iradesi bulunmaksızın gerçekleştirilmişse, burada koruma amacıyla özgürlüğün kısıtlanmasının söz konusu olduğu kabul edilmelidirr ${ }^{92}$. Burada mesele,

\footnotetext{
Krş., Müller, s. 288, 169 vd.

2 Krş., Müller, s. 171-172; BSK ZGB I- Affolter, Art. 405 N 59; BSK ZGB I- Geiser, Art. 405a N 5.
} 
küçügün somut haldeki korunma ihtiyacının karşılanarak onun hangi sebepten kaynaklanırsa kaynaklansın veya hangi derecede olursa olsun içinde bulunduğu zayıflık halinin aşılmasıdır ve bu suretle küçüğün yararının gerçekleştirilmesidir; nihayetinde amaç, küçüğe, erginliğine eriştiğinde hayatını tek başına sürdürmeye muktedir bir insan olarak bağımsız bir kişiliğin kazandırılmasıdır.

Müller'e göre küçüğün koruma amacıyla özgürlüğünün kısıtlanması anlamında bir kuruma yerleştirilmesi, vasinin Art. 405 ZGB / TMK 445 hükmü uyarınca özen yükümünü gereği gibi yerine getirmesi halinde alınması olağan önlemlerle örtüşmez ${ }^{93}$. Gerçekten de küçüğün koruma amacıyla özgürlügünün kısıtlanması anlamında bir kuruma yerleştirilmesi, küçüğün somut haldeki korunma ihtiyacının başka şekilde sağlanamaması sebebiyle başvurulan son çare (ultima ratio) niteliğindedir ${ }^{94}$ ve esasen küçüğün koruma amaciyla bir kuruma yerleştirilmesine, gecikmesinde sakınca bulunan haller dışında, vasinin başvurusu üzerine vesayet makamı karar verir. Öte yandan gecikmesinde sakınca bulunan hallerde vasi, küçügün kuruma yerleştirilmesine bizzat karar verse de durumu derhal vesayet makamına bildirmekle yükümlüdür. Bununla birlikte vurgulamak gerekir ki küçüğün özgürlüğünün kısıtlanması, daha önce de ifade edildiği gibi, küçüğün yararının korunmasına yönelik bir önlem olarak vasinin özen yükümünü tamamlayıcı bir fonksiyon gösterir ${ }^{95}$.

\section{Vesayet Altındaki Küçüğün Gözetim Altında Eğitiminin} Gerekli Olması

Vesayet altındaki küçüğün koruma amaciyla özgürlüğünün kısıtlanması anlamında bir kuruma yerleştirilebilmesi için onun gözetim altında eğitimi gerekli görülmelidir ${ }^{96}$. Bu şart, daha önce de ifade edildiği üzere, Avrupa İnsan Hakları Sözleşmesi'nden kaynaklanmaktadır. Gerçi Sözleşme'nin ilgili hükmünde (m. 5/I-d) küçügün gözetim altında eğitimi amacıyla usulüne uygun olarak tutulmasından söz edilmektedir. Ancak doktrinde sözü edilen amaçtan hareketle, özgürlüğünün kısıtlanabilmesi için küçüğün gözetim altında eğitiminin gerekliliği sonucuna varılmaktadır ${ }^{97}$.

Küçügün gözetim altında eğitimi, vasi tarafından küçüğe gösterilmesi gereken özen çerçevesinde ele alınmalıdır ${ }^{98}$. Yukarıda da ifade edildiği gibi, vasi, özen yükümü uyarınca küçügün bakımı ve eğitimi için gereken

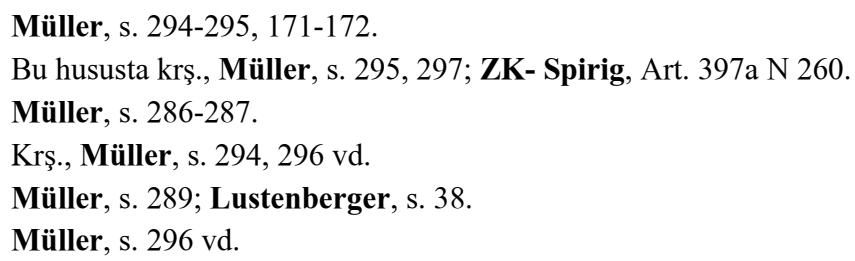


önlemleri almalıdır. Küçüğün bakımı ve eğitiminden maksat, küçüğün temel ihtiyaçlarının karşılanmasıyla birlikte, onun bedensel, zihinsel, ruhsal, ahlaki ve toplumsal gelişiminin sağlanması ve korunmasıdır (TMK 445/I, II ve 339/I, 340/I) ${ }^{99}$. Bu suretle küçüğün zayıflığının dengelenerek her halükarda küçügü̈n yararının gerçekleştirilmesine çalışılır. Nihai amaç, daha önce de ifade edildiği gibi, küçüğe, ileride kendi sorumluluğunun bilincinde bağımsız bir ergin olarak tek başına yaşama ve topluma uyum ehliyetinin kazandırılmasıdır. Küçüğün gözetim altında eğitiminde ise, küçüğün somut halde ihtiyaç duyduğu bakım ve eğitimin, buna elverişli bir kurum ortamında, kurum düzeni içinde gerçekleştirilmesi söz konusu olmaktadır (Mesela korunmaya muhtaç küçüklerin sosyal hizmet kuruluşlarında bakılıp yetiştirilmelerinde olduğu gibi ${ }^{100}$. Aslında küçügün gözetim altında eğitiminin gerekliliği ile küçüğün kişisel korunmasının somut halde başka şekilde sağlanamaması arasında sıkı bir ilişki mevcuttur ${ }^{101}$. Bu noktada küçügün kişisel korunmasının ancak koruma amaciyla özgürlüğün kısıtlanması anlamında uygun bir kurum ortamında sağlanabilmesi durumunda, burada küęüğün gözetim altında eğitimi amacının da bulunduğu kabul edilmelidir ${ }^{102}$.

Doktrinde gözetim altında eğitim kavramının geniş yorumlanması gerektiği ifade edilmektedir ${ }^{103}$. Buna göre gözetim altında eğitim, salt koruyucu nitelikteki önlemlerin yanı sıra gençlik ceza hukukuna ilişkin önlemleri de kapsar. Ancak Lustenberger'e göre bu kavram, herhangi bir küçüğün böyle bir önleme katlanabileceği şeklinde de anlaş1lamaz ${ }^{104}$. Lustenberger'e göre gözetim altında eğitim, sadece içinde bulundukları özel şartlar sebebiyle buna ihtiyaç gösteren küçükler bakımından yerindedir. Mesela manen terk edilmiş veya fiziksel engeli bulunan küçüklerde olduğu gibi. Küçüğün gözetim altında eğitiminde, küçüğün içinde bulunduğu belirli bir zayıflık halinden ziyade, bu zayıflık halinin belirli bir yoğunluk göstermesi önemlidir ${ }^{105}$. Müller'e göre burada küçüğün zayıflığ1, Art. 405 ZGB/TMK 445 çerçevesinde alınan önlemlerle dengelenemeyecek bir dereceye erişmiştir; bu ise aynı zamanda küçüğün ihtiyaç duyduğu bakım ve eğitimin sağlanamadığı bir durumu da ifade etmektedir. Aslında bu, küçüğün

\footnotetext{
99 Krş., Müller, s. 296 vd., 130 vd., 221 vd., 238 vd.; BSK ZGB I- Affolter, Art. 405 N 23 $\mathrm{vd}$.

100 Krş., Müller, s. 297; Lustenberger, s. 38; BGE 121 III 306 (308-309).

101 Krş., Müller, s. 296.

102 Krş., Müller, s. 297. Bu hususta velayet altındaki küçük bakımından bkz. ve krş., Lustenberger, s. 39; Tuor/Schnyder/Rumo-Jungo, s. 452-453; BB1 1977 III 46; Schubarth, s. 476.

103 Müller, s. 296; Lustenberger, s. 38-39.

104 Lustenberger, s. 39.

105 Lustenberger, s. 39.
} 
yararının tehlikeye düşmesi halidir. Bu noktada da küçüğün gözetim altında eğitiminin gerekliliği ortaya çıkmaktadır ${ }^{106}$.

Gerçekten de bu yönde gözetim altında eğitimin, daha ziyade tehlikeye düşmüş, manen terk edilmiş, suça eğilimli veya suç işlemiş küçükler bakımından gerekli görüldügüü hususu ifade edilmelidir. Burada küçük için gerekli görülen bakım ve eğitimin, buna elverişli ve bu maksatla kurulmuş bir kurumda küçüğün özgürlügünün k1sıtlanmas1 suretiyle sağlanması yönüne gidilir. Böylelikle küçüğün zayıflığının dengelenmesine ve küçüğün yararına yönelik tehlikenin bertaraf edilmesine çalışılır; küçüğün zarar görmüş bulunması halinde ise küçüğün sağaltımı için çaba gösterilmelidir.

Öte yandan küçüğün gözetim altında eğitiminin gerekli olup olmadığını tespit etmek amacıyla da küçügün koruma amaciyla özgürlügünün kısıtlanması anlamında bir kuruma sevk edilmesi mümkündür ${ }^{107}$.

\section{Uygun Bir Kurumun Bulunması}

Vesayet altındaki küçüğün koruma amacıyla özgürlüğünün kısıtlanabilmesi için yukarıda yer verilen şartlarla birlikte, somut halde küçüğün yerleştirilebileceği uygun bir kurumun bulunması da gereklidir ${ }^{108}$.

Burada öncelikle koruma amacıyla özgürlüğün kısıtlanması anlamında kurum kavramından ne anlaşılması gerektiği hususu üzerinde durulmalıdır. Vesayet altındaki küçügün koruma amaciyla bir kuruma yerleştirilebileceğini öngören TMK 446'da kurum kavramı tanımlanmamıştır ${ }^{109}$.

İsviçre'de koruma amacıyla özgürlüğün kısıtlanmasına ilişkin kanun tasarısının izahında kurum kavramı, oldukça geniş bir anlamda ele alınmıştır $^{110}$. Buna göre kişiye yönelik özenin, kişinin özgürlüğünün kısıtlanması suretiyle, kişinin iradesi bulunmaksızın veya iradesine karşı gerçekleştirilebildiği çeşitli tesisler, koruma amacıyla özgürlüğün kısıtlanması anlamında kurum kavramı içinde değerlendirilir. Burada kurumun, kapalı bir tesis olması şart değildir; kuruma yerleştirilen kişinin,

106 Müller, s. 297.

Müller, s. 274; krş., BSK ZGB I- Geiser, Art. 405a N 4.

Müller, s. 294, 298 vd.

109 Kurum kavramı, kaynak Art. 405a ZGB hükmünde de tanımlanmamıştır. Bu hususta bkz., Müller, s. 298 vd. Ayrıca TMK 432 hükmüyle ilgili açıklamalar çerçevesinde Dural/Öğüz/Gümüş, s. 694.

110 BBl 1977 III 28 vd.; ayrıca Müller, s. 299; Lustenberger, s. 80 vd. 
kurumu terk edememesi yeterlidir. Kurum kavramının, farklı görüşlerle birlikte doktrinde de geniş yorumlandığını ifade etmek mümkündür ${ }^{111}$.

TMK 446 hükmü çerçevesinde de geniş bir kurum kavramından hareket edilmelidir. Kişisel özgürlüğe yönelik ağır bir müdahale teşkil etmesi sebebiyle koruma amacıyla özgürlüğün kısıtlanmasına ilişkin düzenlemelerde kişinin kişisel özgürlüğü bakımından olabildiğince kapsamlı bir hukuki korumadan yararlanması hedeflenmiştir ${ }^{12}$. Mesele şudur ki koruma amacıyla kişinin özgürlüğü haksız yere kısıtlanmamalıdır. TMK 446 hükmündeki düzenlemenin hedefi de bu yönde olmalıdır. Bu noktada normun amac1 göz önünde bulundurulduğunda, küçüğün yerleştirileceği kurum kavramının da geniş yorumlanması gerekir; zira bu suretle TMK 446 hükmünün öngördüğü hukuki korumadan daha çok sayida küçüğün yararlanması imkanı sağlanmış olacaktır ${ }^{113}$.

$\mathrm{Bu}$ açıklama bağlamında TMK 446 anlamında kurumdan söz edilebilmesi için her şeyden önce ilgili kurumda küçüğün kişisel özgürlügüne yönelik bir müdahale vuku bulmalıdır ${ }^{114} . \mathrm{Bu}$ müdahalenin değerlendirilmesinde kurumun yapısal planı, coğrafi konumu, iç yapısı, yönetilme biçimi, amacı ve kuruma yerleştirilenlere karşı tutumu gibi hususlar da dikkate alınır ${ }^{15}$. Ancak vurgulanmalıdır ki burada küçüğün kişisel özgürlüğüne yönelik müdahalenin derecesi önemlidiir ${ }^{116}$. İsviçre doktrininde bu yönde mesela küçüğün hareket özgürlüğünün kısıtlanmasının ön planda bulunduğu, özellikle küçüğün alıştığı çevreden izole edildiği kapalı tesislerin Art. 405a ZGB/TMK 446 anlamında kurum niteliğini taşıdığ 1 kabul edilmektedir ${ }^{117}$. Küçüğün özgürlüğüne yönelik müdahalenin derecesi, ortalama bir aile çevresinde bulunan yaşıtlarıyla karşılaştırılarak değerlendirilir. Bu bağlamda kişisel özgürlüğe yönelik kısıtlamaların tamamı göz önünde tutulduğunda küçüğün özgürlüğü, yerleştirildiği kurumda, ortalama bir ailede bulunan yaşıtınınkine göre açıkça daha geniş derecede kisitlanıyorsa, burada Art. 405a ZGB/TMK 446 anlaminda bir kurum söz konusudur $^{118}$. Bu yönde mesela onyedi yaşındaki küçügün her gün iş sonrası

111 Bu hususta Müller, s. 300; Lustenberger, s. 81, 82 vd.; BSK ZGB I- Geiser, Art. 397a N 22 vd.; ZK- Spirig, Art. 397a N 119 vd.; Tuor/Schnyder/Rumo-Jungo, s. 514; Caviezel-Jost, s. 349 vd., 359, 360 vd., 366; Suhr Brunner, s. 114 vd.; BGE 121 III 306 (308 vd.). Türk hukukunda Dural/Öğüz/Gümüşs, s. 694 vd.

112 Bu hususta Caviezel-Jost, s. 359 vd.; Lustenberger, s. 79 vd., 82 vd.; Müller, s. 300.

113 Krş., Müller, s. 300; Lustenberger, s. 79, 80 vd.; Caviezel-Jost, s. 359.

114 Krş., Müller, s. 299, 300-301; Lustenberger, s. 83 vd.

115 Müller, s. 299, 301; Lustenberger, s. 86.

16 Müller, s. 301; Lustenberger, s. 87.

117 Müller, s. 301, 299; Lustenberger, s. 86, 91 vd.

118 Müller, s. 299-300; Lustenberger, s. 104; BSK ZGB I- Affolter, Art. 405 N 59; ayrica bkz. ve krş., BSK ZGB I- Geiser, Art. 405a N 5; Tuor/Schnyder/Rumo-Jungo, s. 453, dn.43; Hegnauer, N 27.66; BGE 121 III 306 (308 vd.); SJZ 1988, s. 65. 
saat 19.30 'dan itibaren kurumda kalma yükümünün bulunması ve bunun kontrole tabi tutulmas halinde, burada Art. 405a ZGB/TMK 446 anlamında bir kurumun olduğu kabul edilmelidir; yine mesela kurumun öncelikle küçügü eğitsel açıdan düzeltici bir amacı takip etmesi ve bunu psikoterapi gibi özel tedavilerle desteklemesi halinde, küçügün yerleştirildiği tesisin Art. 405a ZGB/TMK 446 anlamında bir kurum olduğu sonucuna varmak mümkündür ${ }^{119}$.

Küçüğün koruma amacıyla özgürlüğünün kısıtlanması anlamında kuruma yerleştirilebilmesi için ölçülülük ilkesi uyarınca kurumun buna elverişli olması gerekir ${ }^{120}$. Diğer bir ifadeyle kurum, küçüğü koruma amacı bakımından uygun bulunmalıdır. Bu yönde kurum, küçügün somut halde ihtiyaç duyduğu bakımı ve eğitimi sağlayabilecek, küçüğün yararına yönelik tehlikeleri bertaraf edebilecek nitelikte olmalıdır; keza küçüğün yerleştirildiği kurum, onu ileride kurum dışındaki hayatına hazırlayabilmelidir; yine kurum, gelişimi kesintiye uğramış, zarar görmüş küçügün sağaltımına yardımda bulunabilmelidir ${ }^{121}$. Bu bağlamda kurum, gerekli araçlara ve nitelikli personele sahip olmalıdır. Ancak vurgulanmalıdır ki küçüğün yerleştirileceği kurumun uygunluğundan maksat, kurumun ideal olması değildir; burada söz konusu olan, kurumun, ölçülülük ilkesi çerçevesinde somut halde küçük için en uygun alternatifi teşkil etmesidir ${ }^{122}$. Yerleştirildiği kurumda küçüğün özgürlüğ̈̈̈, takip edilen koruma amacının gerektirdiği kadar kısıtlanmalıdır ve bu yönde küçüğün özgürlüğüne yönelik müdahalenin ağırlı̆̆ ile gerçekleşmesi mümkün sonucun değeri arasında oran bulunmalıdır. Esasen burada kişisel özgürlüğüne müdahale suretiyle küçük bakımından sağlanan yararın, ona verilen zarardan üstün gelmesi gerekir $^{123}$.

V. Vesayet Altındaki Küçüğün Koruma Amacıyla Özgürlüğünün Kısıtlanmasında Yetki ve Usul

\section{Genel Olarak}

Gerekli şartların gerçekleşmiş bulunması halinde vesayet altındaki küçüğün koruma amacıyla özgürlüğünün kısıtlanması yönüne gidilir ${ }^{124} . \mathrm{Bu}$

119 Örnekler için Müller, s. 300; Lustenberger, s. 105-106.

120 Müller, s. 302 vd.; koruma amacıyla özgürlüğün kısıtlanmasında kurumun elverişliliğine ilişkin olarak ayrıca bkz., Caviezel-Jost, s. 368 vd.; BSK ZGB I- Geiser, Art. 387a N 24 vd.; ZK- Spirig, Art. 397a N 123 vd.; Tuor/Schnyder/Rumo-Jungo, s. 514; Türk hukukunda Dural/Öğüz/Gümüş, s. 694 vd.

121 Müller, s. 302-303, 334; krş., Caviezel-Jost, s. 370, 374.

122 Müller, s. 302; krş., Tuor/Schnyder/Rumo-Jungo, s. 514.

123 Müller, s. 302; krş., Caviezel-Jost, s. 372 vd.

124 Krş., Müller, s. 305. 
bağlamda küçüğün bir kuruma yerleştirilmesi veya halihazırda kurumda bulunuyorsa orada alıkonulması söz konusu olur.

TMK 446 hükmü, küçüğün koruma amaciyla kuruma yerleştirilmesinde yetkiye ilişkin olarak ilk fikrasında doğrudan bir düzenlemeye yer vermiş; bunun dişında usul ve yetkiyle ilgili konularda erginlerin koruma amacıyla özgürlüklerinin kısıtlanmasına ilişkin hükümlere (TMK 433-437) atıfta bulunmuştur (f. 2). 446. maddenin üçüncü fikrasında ise kuruma yerleştirilme kararına itirazla ilgili doğrudan bir düzenleme yer almıştır; buna göre onaltı yaşını doldurmamış küçük, bu konuda mahkemeye bizzat başvuramaz ${ }^{125}$.

Aşağıda TMK 446 hükmünün içerdiği düzenleme bağlamında vesayet altındaki küçüğün koruma amacıyla özgürlüğünün kısıtlanmasında yetki ve usul ele alınacaktır.

\section{Yetki}

TMK 446/I hükmüne göre "küçüklerin koruma amaciyla bir kuruma yerleştirilmesine vasinin başvurusu üzerine vesayet makamı veya gecikmesinde sakinca bulunan hallerde bizzat vasi karar verir ve durumu derhal vesayet makamına bildirir". Bu fikra hükmünün dışında yetkiyle ilgili konularda, 446. maddenin ikinci fıkrasında yapılan atıf gereği, erginlerin koruma amacıyla özgürlüklerinin kısıtlanmasındaki yetkiye ilişkin TMK 433 ve bildirim yükümlülüğü hakkındaki TMK 434 hükümleri de uygulanırr ${ }^{126}$.

Yukarıda anılan hükümlere göre vesayet altındaki küçüğün koruma amacıyla bir kuruma yerleştirilmesine veya orada alıkonulmasına karar verme yetkisi, küçüğün yerleşim yeri vesayet makamına aittir ${ }^{127}$. Vesayet makamı, vasinin başvurusu üzerine karar verir ${ }^{128,129}$. Burada vasi ve vasiyet

125 Kaynak Art. 405a ZGB hükmündeki düzenlemeye ilişkin olarak Müller, s. 305 vd., 283285.

126 Krş., Dural/Öğüz/Gümüş, s. 633-634; İsviçre hukukunda Art. 405a hükmüne ilişkin olarak bkz. ve krş., Müller, s. 305 vd., 313 vd.; BSK ZGB I- Geiser, Art. 405a N 6-11, N 13, Art. 397c N 5; ZK- Spirig, Vor Art. 397a-f, N 37. Bu noktada ifade etmek gerekir ki İsviçre hukukuna göre kantonlar, gecikmesinde sakınca bulunan hallerde veya psişik hastalıklarda koruma amacıyla özgürlügün kısıtlanması kararı alma yetkisini uygun görülen başka mercilere de tanıyabilirler (Art. 397a Abs. 2 ZGB). İsviçre doktrininde Art. 405a Abs. 2 (TMK 446/II)'de yapılan atfın bu düzenlemeyi de kapsadığı kabul edilmektedir (Müller, s. 311-312; BSK ZGB I- Geiser, Art. 405a N 10, krş., N 8, ayrıca Art. 397c N 5).

127 Dural/Öğüz/Gümüş, s. 633; krş., Müller, s. 306; BSK ZGB I- Geiser, Art. 405a N 6-7.

128 Dural/Öğüz/Gümüş, s. 633; krş., Müller, s. 307-308; BSK ZGB I- Geiser, Art. 405a N 7.

129 Gümüș'e göre Kanun'da öngörülmüş bulunmasa da vesayet makamı, diğer ilgililerin (mesela küçüğün ana babasının) başvurusu üzerine re'sen araştırma yetkisi çerçevesinde harekete geçerek vesayet altındaki küçük hakkında koruma amacıyla özgürlüğün kısıtlanması kararı alabilir (Dural/Öğüz/Gümüş, s. 633, dn.223). 
makam1, birlikte hareket etmelidir ${ }^{130}$. Somut halde vesayet makamının küçüğün özgürlüğünün kısıtlanmasının gerekli olduğunu tespit ettiği, fakat vasinin bu yönde başvuruda bulunmadığı bir durum ortaya çıkabilir. $\mathrm{Bu}$ halde Geiser'e göre vesayet makamı, küçüğün özgürlüğünün kısıtlanmasına kendiliğinden karar veremez; ancak vasiye gerekli başvuruda bulunması hususunda talimat verebilir ${ }^{131}$.

TMK 446/I uyarınca gecikmesinde sakınca bulunan hallerde küçüğün koruma amaciyla bir kuruma yerleştirilmesine bizzat vasi karar verir ve durumu derhal vesayet makamına bildirir. Müller'e göre koruma amaciyla özgürlüğün kısıtlanması bakımından gecikmesinde sakınca bulunan hal şöyle ifade edilebilir ${ }^{132}$ : Burada küçüğün somut haldeki zayıflığı ve buna bağl1 olarak özel korunma ihtiyacı, öyle akut bir hale gelmiştir ki küçüğün yararının korunması için olabildiğince hızlı hareket edilmesi zorunluluğu doğmuştur ve onun elverişli bir kuruma yerleştirilmek suretiyle derhal gözetim altında eğitim alması, tek uygun çare olarak görülmüş bulunmaktadır. Böyle özel bir durumun gerçekleşmesi halinde vasi, kanun gereği tek başına küçüğün uygun bir kuruma yerleştirilmesine veya orada alıkonulmasina karar verme yetkisine sahiptir. Bununla birlikte burada vasinin küçüğün kuruma yerleştirilmesi hakkındaki kararına ilişkin olarak vesayet makamının iznine veya onayına gerek bulunup bulunmadığ 1 üzerinde durulmalıdır ${ }^{133}$.

İsviçre'de 1978 revizyonu ile getirilen düzenleme çerçevesinde vasinin gecikmesinde sakınca bulunan hallerde küçüğün kuruma yerleştirilmesine ilişkin olarak tek başına aldığ makamı tarafından onaylanması öngörülmemiştir ${ }^{134}$. Öte yandan anılan revizyonla vesayet altındaki kişinin bir eğitim, bakım veya sağlık kurumuna yerleştirilmesini vesayet makamının iznine bağlayan Art. 421 Ziff. 13 ZGB hükmü de yürürlükten kaldırılmıştır ${ }^{135}$. Müller'e göre gecikmesinde sakınca bulunan hallerde vasi, vesayet makamının izin veya onayına gerek

130 Müller, s. 307 vd.

131 BSK ZGB I- Geiser, Art. 405a N 7. Așağıda da ele alınacağı üzere Müller, gecikmesinde sakınca bulunan hallerde vesayet makamının kendiliğinden harekete geçebileceği görüşündedir (s. 311, 283-284). Hegnauer'e göre vesayet altındaki küçüğün yararı tehlikeye düşmüşse ve vasi çare temin etmiyorsa, bu halde vesayet makamı, kendiliğinden veya küçüğün ya da üçüncü kişilerin başvurusu üzerine küçüğün korunması için gereken önlemleri alır; burada gerekirse küçüğe Art. 392 Ziff. 2 (TMK 426/b.2) hükmüne göre bir temsil kayyımı atanır (N 27.08a).

132 Müller, s. 308; krş., BSK ZGB I- Geiser, Art. 397b N 5.

133 Bu hususta Müller, s. 309 vd.; BSK ZGB I- Geiser, Art. 405a N 9; Türk hukukunda Dural/Öğüz/Gümüş, s. 633 .

134 BSK ZGB I- Geiser, Art. 405a N 9, krş., Art. 397b N 20.

135 BSK ZGB I- Geiser, Art. 405a N 9, Art. 421/422, N 25. 
bulunmaksızın küçügü kuruma yerleştirebilir; böyle bir durumda vasinin küçügün yararını korumak için onun kişisel özgürlüğüne müdahalede bulunabilme yetkisi mevcuttur ${ }^{136}$.

Meseleyi Türk hukuku bakımından ele aldığımızda ifade edilmesi gereken şudur ki TMK 446/I hükmünde yer alan düzenleme çerçevesinde de gecikmesinde sakınca bulunan hallerde vasinin küçüğün kuruma yerleştirilmesi hakkındaki kararının vesayet makamının onayına sunulması öngörülmüş değildir. Burada sadece vasinin küçüğün kuruma yerleştirilmesini vesayet makamına derhal bildirmesi hususu öngörülmüştür. Belirtmek gerekir ki bu husus, kaynak İsviçre Medeni Kanunu'nda düzenlenmemiştir ${ }^{137}$. Ancak İsviçre doktrininde vasinin küçügüün kuruma yerleştirilmesi gibi ağır bir önlemden vesayet makamını haberdar etmesinin, vesayet görevinin usulü dairesinde ifasının gereği olduğu ifade edilmektedir ${ }^{138}$.

TMK 446/I hükmündeki düzenleme çerçevesinde vasinin gecikmesinde sakınca bulunan hallerde küçüğün kuruma yerleştirilmesi hakkında bizzat almış olduğu kararın, vesayet makamının izin ya da onayını gerektirmeksizin geçerli olduğu sonucuna varmak gerekir ${ }^{139}$. Bununla birlikte Türk hukuku bakımından TMK 462/b.13 hükmüne işaret edilmelidir. Anılan hüküm, eski Medeni Kanun'da da m. 405/b.13 olarak yer almaktaydı. Sözü edilen eMK 405/b.13 hükmüne karş1lı gelen kaynak Art. 421 Ziff.13 ZGB hükmü, yukarıda da belirtildiği üzere, 1978 revizyonu ile yürürlükten kaldırılmış bulunurken, eMK 405/b.13, Yeni Medeni Kanun'da m. 462/b.13 olarak mevcudiyetini devam ettirmektedir ${ }^{140}$.

TMK 462/b.13 hükmüne göre vesayet altındaki kişinin bir eğitim, bakım veya sağlık kurumuna yerleştirilmesi halinde vesayet makamının izni gereklidir. Bu hüküm dikkate alınırsa, vesayet altındaki küçüğün koruma amacıyla özgürlüğünün kısıtlanmasına ilişkin TMK 446 hükmünde gecikmesinde sakınca bulunan hallerde küçüğün kuruma yerleştirilmesine bizzat karar verebilme suretiyle vasiye tanınan olağanüstü yetkinin ${ }^{141}$ tartışmalı hale gelmesi gerekir. Böyle bir durumda vasi, küçüğün kuruma yerleştirilmesine bizzat karar verse de sonradan bu kararını vesayet makamına onaylatmak zorunda kalacaktır. Diğer bir ifadeyle vasinin kuruma

136 Müller, s. 309.

137 Krş., Dural/Öğüz/Gümüş, s. 633.

138 BSK ZGB I- Geiser, Art. 405a N 9, Art. 397c N 3, N 10; ayrıca Müller, s. 314.

139 TMK 446/I hükmü uyarınca yapılan bildirimden sonra küçüğün kurumdan çıkarılmasına vesayet makamı yetkili olacağından (TMK 446/II ve 433/II), iznin gerekli olup olmadığı tartışmalarının pratik önemi bulunmadığı yönünde Dural/Öğüz/Gümüşs, s. 634.

140 Bkz., Kanun'un gerekçesi (Dn.1), s. 151.

141 Krş., Müller, s. 308, 309 vd. 
yerleştirme kararının geçerliği, vesayet makamının onayına bağlı olacaktır. Halbuki TMK 446/I'de vasiye tanınan olağanüstü yetki ile meseleye pratik bir çözüm getirilmiş bulunulmaktadır. Burada gecikmesinde sakınca bulunan hallerde küçüğün acil korunma ihtiyacının doğrudan vasinin aldığı ve vesayet makamının izin ya da onayını gerektirmeksizin geçerliğe sahip bir karara dayanılarak derhal karşılanması mümkün olmaktadır. Esasen vasi, vesayet görevi çerçevesinde küçü̆ün sorumluluğunu her yönüyle üstlenmiştir ve küçüğün içinde bulunduğu korunma ihtiyacını en iyi takdir edebilecek kişi durumundadır. Bu itibarla gecikmesinde sakınca bulunan hallerde vasinin küçüğün korunma ihtiyacının karşılanabilmesi için gerekli şartlar oluştuğu takdirde onun kişisel özgürlüğüne doğrudan müdahale edebilme yetkisi kabul edilmelidir.

Öte yandan vurgulanmalıdır ki küçügün koruma amacıyla kuruma yerleştirilmesi kararına karşı denetim makamına itiraz imkanı mevcuttur (Bkz., TMK 446/II ve 435). Yine TMK 446/I çerçevesinde vasinin durumu, vesayet makamına derhal bildirme yükümlülügü dolayısıyla da vesayet makamı kendiliğinden harekete geçebilecektir ${ }^{142}$.

Diğer taraftan Türk kanunkoyucusunun, 446. madde bakımından İsviçre kanunkoyucusunu takip ederken, 462/b.13 hükmü bakımından neden farklı bir tutum benimsediği, gerekçeden anlaşılamamaktadır. Burada 462/b.13 hükmünün Kanun'da yanlışlıkla bırakılmış olması, kuvvetle muhtemel görünmektedir.

$\mathrm{Bu}$ açıklamalar çerçevesinde TMK 462/b.13 hükmünü, uygulaması bulunmayan bir hüküm olarak kabul etmek ${ }^{143}$, vesayet altındaki küçüğün koruma amaciyla özgürlüğünün kısıtlanmasına ilişkin düzenlemelerin maksadı ve işlevselliği bakımından en uygun çözümü oluşturacaktır.

Vasinin gecikmesinde sakınca bulunan hallerde küçüğü koruma amacıyla kuruma yerleştirmesi durumunda, bunun süresine ilişkin olarak kaynak İsviçre Medeni Kanunu'nda ve Türk Medeni Kanunu'nda bir düzenleme yer almamaktadır. Bu itibarla küçüğün vasi tarafından kuruma yerleştirilmesine yol açan zayıflık halinin acil müdahale gerektiren akut safhası sona erdikten sonra da küçüğün kurumda tutulmasının gerekli görülmesi durumunda, vasinin olağanüstü yetkisiyle aldığı karara dayanılabilecektir ${ }^{144}$. Ancak Müller'e göre vasinin olağanüstü yetkisi, gecikmesinde sakınca bulunan hallerde derhal alınması gereken acil önlemlerle sinırlıdır ${ }^{145}$; diğer bir ifadeyle koruma amacıyla küçüğün

$142 \mathrm{Krş.,} \mathrm{Dural/Öğüz/Gümüş,} \mathrm{s.} 643$.

143 Bu hususta bkz., Öztan, s. 821, dn.303, 808; Dural/Öğüz/Gümüş, s. 658, 682.

144 Krş., BSK ZGB I- Geiser, Art. 405a N 9.

145 Müller, s. 310. 
özgürlüğüne yapılan ilk müdahaleden sonra küçüğün uzun süre kurumda kalmasını gerektiren bir önleme ihtiyaç duyulduğu takdirde, bu önlem vesayet makamı tarafindan alınmalıdır.

Müller, gecikmesinde sakınca bulunan hallerde vasinin dışında vesayet makamının da duruma göre küçügün kuruma yerleştirilmesine karar verebileceği görüşündedir ${ }^{146}$. Şöyle ki küçüğün özel korunma ihtiyac1, müdahalenin geciktirilemeyeceği derecede akut hale gelmiş bulunuyorsa vesayet makamı, küçüğün kuruma yerleştirilmesine karar verebilir. Müller'e göre burada dar anlamda gecikmesinde sakınca bulunan bir hal söz konusudur. Bunun dişında vasi, küçüğe gereken özeni göstermiyorsa, bu durumda da vesayet makamı, vasinin faaliyetlerini kontrol etme yükümünden dolayı gerekli adımı atmak zorundadır; aksi takdirde küçüğün yararı tehlikeye düşecektir. Müller'e göre burada da geniş anlamda gecikmesinde sakınca bulunan bir hal söz konusudur. Vesayet makamının müdahalede bulunduğu hallerde, vasinin önceden başvurusu gerekli değildir. Diğer bir ifadeyle burada vesayet makamı, kendiliğinden harekete geçerek küçügü uygun bir kuruma yerleştirebilecektir. Müller'e göre Art.405a (TMK 446) hükmünün anlam ve amacı bunu gerektirir ${ }^{147}$.

Öte yandan Müller'e göre gecikmesinde sakınca bulunan hallerde küçüğün yerleşim yeri vesayet makamının yanı sıra bulunduğu yer vesayet makamı da küçüğün kuruma yerleştirilmesine karar verebilir ${ }^{18}$. Zira mesele, korunma ihtiyacı içindeki küçük için gerekli görülen acil bir önlemin derhal alınmasının sağlanmasıdır. O halde küçüğün yararına Art.405a Abs. 2 (TMK 446/II)'de yapılan atıf bağlamında Art. 397b Abs. 1 (TMK 433/I) hükmü çerçevesinde gecikmesinde sakınca bulunan hallerde küçüğün bulunduğu yer vesayet makamının yetkisi kabul edilmelidir.

Bununla birlikte Geiser, Art. 405a Abs. 2 (TMK 446/II) ile Art. 397b Abs. 1 (TMK 433/I) hükmüne yapılan atfın küçüğün bulunduğu yer vesayet makamını kapsamadığ1 görüşündedir ${ }^{149}$. Zira Art. 405a Abs. 1 (TMK 446/I) bağlamında küçüğün kuruma vasinin başvurusuna bağlı olarak yerleştirilmesi halinde, işlemin seyri daha hızlı olmayacaktır. Üstelik küçügün bulunduğu yer vesayet makamı, küçüğü ve vasiyi yeterince tanımadığı için gecikmelere de yol açabilecektir.

Kanımızca gecikmesinde sakınca bulunan hallerde küçüğün yerleşim yeri veya bulunduğu yer vesayet makamının doğrudan müdahale ederek

146 Müller, s. 308, 310-311.

147 Krş., Müller, s. 311, 283-284.

148 Müller'e göre gecikmesinde sakınca bulunan hallerde küçüğün yerleşim yeri veya bulunduğu yer denetim makamı da kuruma yerleştirmeye karar verebilir (Krş., s. 311).

149 BSK ZGB I- Geiser, Art. 405a N 8. 
küçüğü bir kuruma yerleştirme yetkisi kabul edilmelidir. Burada önemli olan, somut halde küçüğün acilen ihtiyaç duyduğu korunma ve desteğin olabildiğince hızlı bir biçimde sağlanmasıdı1 ${ }^{150}$.

TMK 446/II'nin atıfta bulunduğu TMK 433/II hükmüne göre küçüğün kuruma yerleştirilmesine karar veren vesayet makam1, kurumdan çıkarılmasına da yetkilidir ${ }^{151}$. Gecikmesinde sakınca bulunan hallerde küçügün kuruma yerleştirilmesine vasinin karar vermesi durumunda da Türk Medeni Kanunu'nda açılık olmamakla birlikte, kurumdan çıkarma bakımından vesayet makamının yetkili olduğu kabul edilmelidir. Burada TMK 446/I hükmü uyarınca vasinin, küçüğün kuruma kendisi tarafindan yerleştirildiğini derhal vesayet makamına bildirmekle yükümlü bulunduğu göz önünde tutulmalıdır ${ }^{152}{ }^{153}$.

Diğer taraftan TMK 446/II ile yapılan atıf çerçevesinde dikkate alınması gereken bir diğer hüküm de TMK 434 hükmüdür. Burada bildirim yükümlülüğü öngörülmüştür. Anılan hükme göre "kısıtlı bir kişi bir kuruma yerleştirildiği veya alıkonulduğu ya da ergin bir kişi hakkında vesayete ilişkin diğer önlemlerin alınmasına gerek görüldüğü takdirde, kişinin bulunduğu yer vesayet makamı veya özel kanunlarda öngörülen ilgililer ${ }^{154}$, durumu yerleşim yeri vesayet makamına bildirmekle yükümlüdürler”. Şu halde mesela gecikmesinde sakınca bulunan hallerde küçügün kuruma yerleştirilmesine bulunduğu yer vesayet makamının karar vermesi durumunda, yerleştirmeye karar veren vesayet makamı, durumu küçüğün yerleşim yeri vesayet makamına bildirmelidir ${ }^{155}$. Bildirimle birlikte küçüğün kurumdan çıkarılması bakımından artık yerleşim yeri vesayet makamının yetkili olduğu kabul edilmelidir ${ }^{156}$. TMK 434 hükmünde yer almamakla birlikte bildirim yükümlülüğü, küçüğün yerleşim yeri vesayet makamı tarafından kuruma yerleştirilmesinden sonra yerleşim yerinin değişmesi

150 Krş., Müller, s. 311; BB1 1977 III 30-31.

151 İsviçre hukuku bakımından bu hususta BSK ZGB I- Geiser, Art. 405a N 11; Müller, s. 312.

152 Vasinin TMK 446/I uyarınca bildirimde bulunmasından sonra TMK 433/II'nin kıyasen uygulanmasıyla küçüğün kurumdan çıkarılmasına vesayet makamının yetkili olacağı yönünde Dural/Öğüz/Gümüş, s. 634.

153 İsviçre hukukunda küçügün vasi tarafından kuruma yerleştirilmesi halinde, küçüğün kurumdan çıkarılmasına yerleştirildiği kurum karar verir (Art. 405a Abs. 2 ve Art. 397b Abs. 3). Bu hususta bkz. ve krş., Müller, s. 312-313; BSK ZGB I- Geiser, Art. 405a N 11, Art. 397b N 20, N 18-19.

154 "İlgililer" olarak nüfus memurları, idari makamlar, noterler, mahkemeler sayılabilir (Dural/Öğüz/Gümüşs, s. 698); krş., BSK ZGB I- Geiser, Art. 397c N 7.

155 Müller, s. 314.

156 Krş., BSK ZGB I- Geiser, Art. 397b N 16. 
halinde de kabul edilmelidir ${ }^{157}$. Şöyle ki burada küçüğün kuruma yerleştirilmesine karar vermiş bulunan eski yerleşim yeri vesayet makamının durumu yeni yerleşim yerindeki vesayet makamına bildirmesi gerekir; aksi takdirde bildirim yapılıncaya kadar küçüğün kurumdan çıkarılmasına eski yerleşim yerindeki vesayet makamı karar verir (TMK 446/II ve TMK 433/II). Öte yandan ifade edilmelidir ki küçüğün gecikmesinde sakınca bulunan hallerde doğrudan vesayet makamı tarafindan kuruma yerleştirilmesi durumunda, kanuni temsilci olarak vasinin de haberdar edilmesi gerekir ${ }^{158}$.

\section{Usul}

\section{a. Genel Olarak}

Vesayet altındaki küçüğün koruma amacıyla özgürlüğünün kısıtlanmasında usulle ilgili konularda, yukarıda da ifade edildiği gibi, TMK 446/III hükmüyle birlikte TMK 446/II'de yapılan atıf bağlamında erginlerin korunması amacıyla özgürlüklerinin kısıtlanmasına ilişkin hükümlerin (TMK 435-437) uygulanması söz konusu olacaktır.

$\mathrm{Bu}$ başlık altında TMK 436 hükmü üzerinde durulacaktır. Anılan hükümde koruma amacıyla özgürlügün kısıtlanması sürecinde mutlaka uyulması gereken belirli usul kuralları öngörülmüş bulunmaktadır ${ }^{159}$; bunun dışında koruma amaciyla özgürlüğün kisitlanması, Hukuk Usulü Muhakemeleri Kanununa tabidir. Söz konusu kurallar, TMK 436 hükmünde beş bent halinde düzenlenmiş olup, burada aşağıdaki başlıklar altında vesayet altındaki küçüğün koruma amacıyla özgürlüğünün kısıtlanması bakımından uygulanması ele alınacaktır:

-Küçüğün Bilgilendirilmesi

Küçügün bilgilendirilmesine ilişkin olarak öncelikle TMK 436/b.1 hükmü üzerinde durmak gerekir. Bu hüküm uyarınca "karar verilirken ilgilinin bunun sebepleri hakkında bilgilendirilmesi ve karara karşı denetim

157 Krş., BSK ZGB I- Geiser, Art. 397c N 4, Art. 397b N 16, Art. 405a N 11.

158 Müller, s. 314; krş., BSK ZGB I- Geiser, Art. 397c N 8-9, N 18.

159 Bu hususta bkz., Dural/Öğüz/Gümüş, s. 705 vd.; Öztan, s. 808 vd.; Akıntürk, s. 507 vd.; Kılıçoğlu, Ahmet: Medeni Kanun'umuzun Aile - Miras - Eşya Hukukuna Getirdiği Yenilikler, Genişletilmiş 2. Bası, Ankara 2004, s. 165 vd.; Gençcan, Ö. Uğur: "Koruma Amacıyla Özgürlüğün Kısıtlanması Davaları”, Adalet Dergisi, Yı1 93, Temmuz 2002, Say1 12, s. 46 vd. İsviçre doktrininde TMK 436 / Art. 397e ZGB hükmünde öngörülen usul kurallarıyla koruma amacıyla özgürlüğü kısıtlanan kişiye sağlanması gereken belirli asgari garantilerin tespit edildiği ifade edilmektedir. Buna ilişkin olarak ve ayrıca konu hakkında bkz., Imhof, Alexander: Der formelle Rechtsschutz, insbesondere die gerichtliche Beurteilung, bei der fürsorgerischen Freiheitsentziehung, Bern 1999, s. 65 vd., 80 vd.; BSK ZGB I- Geiser, Art. 397e N 2 vd.; ZK- Spirig, Art. 397e N 1 vd.; Riemer, § 8 N 8-9; Tuor/Schnyder/Rumo-Jungo, s. 518; Müller, s. 321 vd.; BGE 127 III 385. Türk hukukunda bu yönde Dural/Öğüz/Gümüss, s. 705-706. 
makamına itiraz edebileceğine yazılı olarak dikkatinin çekilmesi zorunludur".

Vesayet altındaki küçüğün koruma amacıyla özgürlüğünün kısıtlanması bakımından ele alındığında bu hükümde sözü edilen kararla kastedilen, küçüğün koruma amaciyla özgürlüğünün kısıtlanması kararıdır $^{160}$. Bu bağlamda küçüğün bir kuruma yerleştirilmesi veya orada alıkonulması kararı söz konusu olabileceği gibi, küçüğün kurumdan çıkarılma talebinin reddi kararı da söz konusu olabilir ${ }^{161}$. Şu halde bu hükme göre koruma amaciyla özgürlüğü kısıtlanan vesayet altındaki küçüğün, kişisel özgürlüğünün kısıtlanması sonucunu doğuran kararın neden alındığına ilişkin olarak bilgilendirilmesi ve bu karara karşı denetim makamına itiraz edebileceğine yazılı olarak dikkatinin çekilmesi gerekmektedir $^{162}$. Doktrinde bazı yazarlara göre TMK 436/b.1 hükmü uyarınca koruma amacıyla özgürlüğün kısıtlanması kararının sebeplerine ilişkin bilgilendirmenin sözlü olarak yapılması yeterlidir; buna karşılık itiraz hakkına ilişkin bilgilendirme, yazılı olarak yapılmalıdır ${ }^{163}$. Öte yandan itiraz hakkına ilişkin bilgilendirmede, bu hakkın hangi sürede ve nasıl kullanılması gerektiği hususu ve başvurulacak yetkili denetim makamı belirtilmelidir ${ }^{164}$.

Küçüğün bilgilendirilmesi için her şeyden önce ayırt etme gücüne sahip olması gerekir ${ }^{165}$. Burada TMK 446/III hükmünün sınırlayıc1 etkisinin

160 Müller, s. 322; Imhof, s. 83, 89; Suhr Brunner, s. 147; ZK- Spirig, Art. 397e N 47, N 48, N 52; BSK ZGB I- Geiser, Art. 397e N 4; BBl 1977 III 33; Dural/Öğüz/Gümüş, s. 706, 707, dn.468; krş., Gençcan, s. 46.

161 Doktrinde TMK 436/b.1 hükmünün kıyasen vesayet makamınca alınan koruma amacıyla özgürlüğün kısıtlanması kararına itiraz üzerine denetim makamının vereceği ve koruma amacıyla özgürlüğün kısıtlanması halini devam ettiren itirazın reddi kararı bakımından da kısmen uygulanması gerektiği ifade edilmektedir; buna göre denetim makamı, itirazın reddi kararına karşı temyiz yoluna başvurulabileceği hususuna dikkat çekmelidir (Dural/Öğüz/Gümüş, s. 707). Konuya ilişkin olarak İsviçre hukukunda bkz. ve krş., Imhof, s. 83, 89; BSK ZGB I- Geiser, Art. 397e N 6; ZK- Spirig, Art. 397e N 52, N 81; Suhr Brunner, s. 147; Müller, s. 322; BB1 1977 III 33. Türk hukuk doktrininde bazı yazarlara göre denetim makamının TMK 435 hükmü çerçevesinde vereceği itirazın kabulü veya reddi yönündeki karar kesin olup, karara karşı temyiz yoluna başvurulamaz (Bkz., Akıntürk, s. 507; Gençcan, s. 51).

162 Krş., Müller, s. 322-323; BSK ZGB I- Geiser, Art. 405a N 12.

163 Bu hususta bkz., Kılıçoğlu, s. 165; Dural/Öğüz/Gümüş, s. 707, krş., s. 706; BSK ZGB I- Geiser, Art. 397e N 4, N 5; Imhof, s. 86-87, 88; Suhr Brunner, s. 147-148; Müller, s. 322-323; BBl 1977 III 33-34; ayrica ZK- Spirig, Art. 397e N 75, N 76-77, N 80. Koruma amacıyla özgürlüğün kısıtlanması kararının sebeplerine ilişkin bilgilendirmenin yazılı olarak yapılması yönünde Akıntürk, s. 508; Gençcan, s. 46.

164 Bkz. ve krş., Dural/Öğüz/Gümüşs, s. 707; Kılıçoğlu, s. 165; Gençcan, s. 47; Imhof, s. 91; ZK- Spirig, Art. 397e N 84; BSK ZGB I- Geiser, Art. 397e N 5; Suhr Brunner, s. 148; Müller, s. 323; BBl 1977 III 35.

165 Krş., BSK ZGB I- Geiser, Art. 405a N 12; Müller, s. 323. 
bulunup bulunmadığı üzerinde durulmalıdır. Daha önce de ifade edildiği gibi, anılan hükme göre küçük, onaltı yaşını doldurmamışsa, ayırt etme gücüne sahip olsa da koruma amacıyla özgürlüğünün kısıtlanması kararına karşı mahkemeye bizzat başvuramaz; diğer bir ifadeyle karara karşı denetim makamına itirazda bulunamaz ${ }^{166}$. Lustenberger, bu hükümden hareketle henüz onaltı yaşını doldurmamış küçüğün koruma amacıyla özgürlüğünü kısıtlayan kararın sebeplerine ve mahkemeye başvurma (itiraz) hakkına ilişkin olarak bilgilendirilmesine gerek bulunmadığını ileri sürmüştür ${ }^{167}$. Böyle bir durumda Art. 397d Abs. 1 ZGB (TMK 435/I) hükmü çerçevesinde küçüğe yakın kişilerin bilgilendirilmesi yönüne gidilmelidir. Gerçi Lustenberger'e göre koruma amaciyla özgürlügün kısitlanması sürecinde karar verilmeden önce küçüğün dinlenilmesi, onun en azından kararın sebeplerine ilişkin olarak aydınlatılmasını gerektirir; fakat bu, Art. 397e Ziff.1 ZGB (TMK 436/b.1) hükmüne göre gerçekleşmemektedir ${ }^{168}$. Kanımızca onaltı yaşını doldurmadığı için mahkemeye bizzat başvurma yetkisine sahip olmasa da küçügün ayırt etme gücünün bulunması halinde koruma amacıyla özgürlüğünün kısıtlanması kararı hakkında TMK 436/b.1 çerçevesinde uygun bir biçimde bilgilendirilmesi gerekir. Zira koruma amacıyla da olsa burada küçüğün en önemli temel haklarından kişisel özgürlüğüne yönelik ağır bir müdahale vuku bulmaktadır ${ }^{169}$. Küçüğün kişiliğine sayg1 gösterilmesi ilkesi, onun hayatını önemli surette etkileyen böyle bir karar hakkında bilgilendirilmesini gerektirir. Burada itiraz hakkının kullanılabilmesi için TMK 435/I hükmü bağlamında küçüğe yakın kişilerin bilgilendirilmesi yönüne gidilmesi ${ }^{170}$, bu sonucu değiştirmemelidir.

$\mathrm{Bu}$ tespitten sonra TMK 436/b.1 hükmü çerçevesinde koruma amacıyla özgürlüğün kısıtlanması kararının sebeplerine ve itiraz hakkına ilişkin olarak TMK 435/I hükmü bağlamında küçüğe yakın kişilerin bilgilendirilmesi meselesi üzerinde durulmalıdır.

Aşağıda da ele alınacağı üzere, sözü edilen TMK 435/I hükmü uyarınca kuruma yerleştirilen kişiden bağımsız olarak yakınlarına da koruma amacıyla özgürlüğün kısıtlanması kararına itiraz hakkı tanınmış bulunmaktadır ${ }^{171}$. Anılan madde hükmünde yer alan yakın kavramına,

166 Bu hususta bkz., Dural/Öğüz/Gümüş, s. 634; Akıntürk, s. 515; BSK ZGB I- Geiser, Art. 405a N 18; Mülller, s. 316; Imhof, s. 139, 140 vd.; Lustenberger, s. 134 vd.

167 Lustenberger, s. 116, 117 vd.; krş., BSK ZGB I- Geiser, Art. 405a N 12; Dural/Öğüz/Gümüş, s. 634.

168 Lustenberger, s. 117.

169 Krş., Lustenberger, s. 117.

170 Bu hususta BSK ZGB I- Geiser, Art. 405a N 12; Müller, s. 316 vd., 322-323; Lustenberger, s. $117 \mathrm{vd}$

171 Yakınların itiraz hakkına ilişkin olarak Dural/Öğüz/Gümüş, s. 701, 702 vd.; Öztan, s. 808; BSK ZGB I- Geiser, Art. 397d N 13 vd.; ZK- Spirig, Art. 397d N 17 vd.; Imhof, s. 138, 140 vd.; Tuor/Schnyder/Rumo-Jungo, s. 516 vd.; Müller, s. 316 vd. 
koruma amacıyla özgürlüğü kısıtlanan kişiyle belirli bir ilişki içinde olup, onun menfaatlerini korumak isteyen kişi çevresi dahildir ${ }^{172}$. Bu noktada ifade etmek gerekir ki kanuni temsilci olarak vasi de yakın kavramı içinde yer alır.

İsviçre'de 1978 revizyonuna ilişkin kanun tasarısının izahında yakın kişilere tanınmış bulunan mahkemeye başvurma (itiraz) hakkından, onların koruma amacıyla özgürlüğün kısıtlanması kararının sebepleri hususunda bilgilendirilme talebinin de doğduğu ifade edilmiştir ${ }^{173}$; ancak tasarı, bilgilendirilme için yakın kişilerin bu yönde açık bir istemde bulunmalarını öngörmüştür ${ }^{174}$. Geiser, yakınların Art. 397e Ziff.1 (TMK 436/b.1) hükmü çerçevesinde bilgilendirilmesini, Art. 397d Abs. 1 (TMK 435/I) hükmü uyarınca koruma amacıyla özgürlügün kısıtlanması kararının bildirilmesiyle bağlantılı olarak ele almıştır. Şöyle ki anılan yazara göre Art. 397d Abs. 1 (Krş., TMK 435/I) hükmündeki "koruma amacıyla özgürlüğün kısıtlanması kararından etkilenen kişinin veya ona yakın bir kişinin karara karşı bildirimden itibaren on gün içinde yazılı olarak mahkemeye başvurabileceğine" ilişkin düzenlemeden bütün yakınların koruma amacıyla özgürlüğün kısıtlanması kararının kendilerine bildirilmesine yönelik bir talebe sahip oldukları sonucu çıkarılamaz ${ }^{175}$. Bununla birlikte koruma amacıyla özgürlüğün kısıtlanması kararı, itiraza yetkili bir kişi çevresine bildirildiği takdirde bu kişiler, Art. 397e Ziff.1 (TMK 436/b.1) hükmündeki haklara sahiptir ${ }^{176}$; diğer bir ifadeyle koruma amaciyla özgürlüğün kısıtlanması kararının sebeplerine ve itiraz hakkına ilişkin olarak bilgilendirilmeleri gerekir.

Esasen ifade etmek gerekir ki yakın kişilerin bilgilendirilmesi, onların kendilerine tanınan itiraz hakkını etkili biçimde kullanabilmeleri bakımından önemlidir ${ }^{177}$. Öte yandan koruma amaciyla özgürlüğ̈̈ kısıtlanan kişinin, mesela ayırt etme gücünün bulunmaması dolayısıyla kararın sebeplerine veya itiraz hakkına ilişsin bilgilendirmeyi anlayamayacağı ya da itiraz hakkını kullanamayacağı bir halde de yakınların bilgilendirilmesi özel önem taşır. Nitekim Federal Mahkeme bir kararında yakınların gereği gibi bilgilendirilmesi halinde, akıl zayıflığından dolayı kuruma yerleştirilmiş bir kişiye hakime başvurma (itiraz) hakkının yazılı olarak bildirilmemiş

172 Krş., Müller, s. 317-318; Lustenberger, s. 139 vd.; Imhof, s. 142 vd.; BSK ZGB IGeiser, Art. 397d N 13; ZK- Spirig, Art. 397d N 24 vd.; Suhr Brunner, s. 145; Dural/Öğüz/Gümüş, s. 703; Öztan, s. 808.

173 BB1 1977 III 34; ayrica Suhr Brunner, s. 148.

174 Müller, s. 322

175 BSK ZGB I- Geiser, Art. 397c N 19, Art. 397d N 20; Imhof, s. 82, 148.

176 BSK ZGB I- Geiser, Art. 397e N 7; Imhof, s. 88; krş., ZK- Spirig, Art. 397e N 65.

177 Krş., Müller, s. 322; Lustenberger, s. 114-115; BSK ZGB I- Geiser, Art. 397e N 4. 
bulunmasının, bu kişiyi mağdur etmeyeceği sonucuna varmıştır ${ }^{178}$. Keza doktrinde koruma amaciyla özgürlügü kısitlanan kişinin ayırt etme gücünün bulunmaması halinde, yakın kavramının özellikle geniş yorumlanması gerektiği de ifade edilmiştir ${ }^{179}$. Burada mesele, itiraz hakkını kullanamayacağı bir halde koruma amacıyla özgürlüğü kısıtlanan kişiye gerekli hukuki korumanın sağlanabilmesidir.

$\mathrm{Bu}$ açıklamaların ardından vesayet altındaki küçük bakımından şu hususlara işaret edilmelidir: TMK 436/b.1 hükmü çerçevesinde koruma amacıyla özgürlügün kısıtlanması kararının sebeplerine ve itiraz hakkına ilişkin olarak küçükle birlikte, vasinin de doğrudan bilgilendirilmesi gerekir $^{180}$. Zira vasi, kanuni temsilcisi olarak küçüğe her aşamada özen göstermekle yükümlüdür ve küçüğün hayatının düzenlenmesinden her yönüyle sorumludur. Özellikle küçüğün ayırt etme gücüne sahip olmaması halinde, küçügün menfaatlerinin korunması bakımından vasinin mutlaka bilgilendirilmesi gerekir ${ }^{181}$. Bu durum, TMK 446/III hükmü uyarınca henüz onaltı yaşını doldurmamış bulunan küçük bakımından da söz konusudur.

Bu noktada şu hususa dikkat çekilmelidir; daha önce de ifade edildiği gibi -istisnai olarak vesayet makamının talimatıyla vasinin başvurusu üzerine veya doğrudan vesayet makamı tarafından kuruma yerleştirildiği hallerin dışında- vesayet altındaki küçüğün koruma amacıyla özgürlüğünün kısıtlanmasına vasinin başvurusu üzerine vesayet makamı karar verir (TMK 446/I). Burada vasinin ve vesayet makamının birlikte hareket etmesi öngörülmüsstür. Diğer yandan gecikmesinde sakınca bulunan hallerde bizzat vasi de küçüğün kuruma yerleştirilmesine karar verebilmektedir. Her iki durumda da vasinin TMK 435/I hükmü çerçevesinde koruma amaciyla özgürlüğün kısıtlanması kararına itiraz etmesini beklemek güçtür; zira vasi, kuruma yerleştirmeyi küçüğün yararı bakımından gerekli gördüğü içindir ki vesayet makamına başvurmuştur veya acil hallerde bizzat karar vermiştir. Özellikle küçüğün bizzat vasi tarafindan kuruma yerleştirilmesi halinde, burada TMK 426/b.2 anlamında menfaat çatışmasından söz etmek mümkündür ${ }^{182}$. Şu halde böyle bir durumda onaltı yaşını doldurmamış bulunan veya ayırt etme gücüne sahip olmayan küçüğün hukuki korumadan yoksun bırakılmaması bakımından küçüğün diğer yakınlarının, mesela ana

178 BGE 114 II 213 (218). Bu hususta bkz., ZK- Spirig, Art. 397e N 64; BSK ZGB IGeiser, Art. 397e N 7; Imhof, s. 90; Dural/Öğüz/Gümüş, s. 707, dn.470; ayrıca krş., Kılıçoğlu, s. 165; Gençcan, s. 46, dn.17.

179 Imhof, s. 143; krş., Lustenberger, s. 141.

180 Bu hususta Müller, s. 322-323; BSK ZGB I- Geiser, Art. 405a N 12, Art. 397c N 18, krş., Art. 397c N 8-9; ZK- Spirig, Art. 397e N 74, Art. 397c N 33; Imhof, s. 82.

181 Krş., Müller, s. 323.

182 Krş., Imhof, s. 199; ZK- Spirig, Art. 397f N 86. 
babasının ya da kuruma yerleştirilmeden önce yanlarında kaldığı ailenin bilgilendirilmesi gerekir ${ }^{183}$. Öte yandan burada somut halde küçüğe yakın kişiler bulunmayabilir veya mevcut yakın, mesela ayırt etme gücünün bulunmaması vb. sebebiyle itiraz hakkını kullanmaya muktedir olmayabilir $^{184}$. Kanımızca böyle bir halde gerekli hukuki korumanın sağlanması için küçüğe kayyım atanması yönüne gidilmelidir (TMK $426 / \mathrm{b} .2)^{185}$.

İfade edilmelidir ki küçüğe yönelik kapsamlı özen yükümüne rağmen vasinin ve diğer yakınların küçük hakkındaki koruma amacıyla özgürlüğün kısıtlanması kararına ilişkin olarak bilgilendirilmesi, sınırsız değildir. Burada sınırı küçüğün kişilik hakkı oluşturur. Buna göre vasi ve diğer yakınlar bilgilendirilirken küçüğün kişilik hakkı ihlal edilmemelidir; küçüğün özel alanının korunmasında haklı bir menfaati varsa, bu gözetilmelidir ${ }^{186}$.

Küçügün bilgilendirilmesi bakımından uygulanması gereken bir diğer hüküm de TMK 436/b.2' dir $^{187}$. Burada kuruma yerleştirilme aşamasındaki bilgilendirme düzenlenmiştir ${ }^{188}$. Anılan hükme göre "bir kuruma yerleştirilen kişiye, alıkonulma kararına veya kurumdan çıkarılma isteminin reddine karş1 en geç on gün içinde denetim makamına itiraz edebileceği derhal yazılı olarak bildirilir". Bu hüküm, genel olarak bir kuruma yerleştirilen herkesi kapsar. Şöyle ki bir kuruma koruma amacıyla özgürlüğün kısıtlanması kararı ile yerleştirilen kişilerin yanı sıra kendi rızasıyla yerleştirilen kişilerin de TMK 436/b.2 çerçevesinde bilgilendirilmesi gerekir ${ }^{189}$. Bilgilendirme, kurum tarafindan yapılır ${ }^{190}$. Vesayet altındaki küçük bakımından ele alındığında; burada da ayırt etme gücüne sahip küçüğün onaltı yaşını doldurmuş bulunup bulunmadığına bakılmaksızın uygun biçimde bilgilendirilmesi gerektiği görüşündeyiz. Ancak TMK 446/III hükmü dolayısıyla kuruma yerleştirilen küçüğün onaltı yaşını henüz doldurmamış bulunması halinde, yukarıda TMK 436/b.1 hükmüne ilişkin açıklamalarımızda olduğu gibi, itiraz hakkının kullanılabilmesi bakımından

\footnotetext{
183 Krş., BSK ZGB I- Geiser, Art. 405a N 12; Müller, s. 323.

184 Krş., Lustenberger, s. 119 vd.

185 Krş., Imhof, s. 199; ZK- Spirig, Art. 397f N 86.

186 Krş., Müller, s. 322; BSK ZGB I- Geiser, Art. 397c N 8-9; Imhof, s. 88; BB1 1977 III 34.

187 Krş., Müller, s. 324; BSK ZGB I- Geiser, Art. 405a N 12; Lustenberger, s. 123 vd.

$188 \mathrm{Bu}$ hususta Dural/Öğüz/Gümüș, s. 708; Öztan, s. 809; Kılıçoğlu, s. 165-166; Imhof, s. 92 vd.; BSK ZGB I- Geiser, Art. 397e N 10 vd.; ZK- Spirig, Art. 397e N 90 vd.; Suhr Brunner, s. 149; BBl 1977 III 35.

189 Imhof, s. 93; ZK- Spirig, Art. 397e N 95; BSK ZGB I- Geiser, Art. 397e N 10; Müller, s. 324; Suhr Brunner, s. 149; Öztan, s. 809; Dural/Öğüz/Gümüş, s. 708.

190 Imhof, s. 93; ZK- Spirig, Art. 397e N 114; BSK ZGB I- Geiser, Art. 397e N 10, N 12.
} 
vasinin veya diğer yakınların bilgilendirilmesi önem taşır ${ }^{191}$. Aynı durum, ayırt etme gücüne sahip olmayan küçük için de geçerlidir. Öte yandan halihazırda bir kuruma yerleştirilmiş bulunan ayırt etme gücüne sahip küçügün burada onaltı yaşını doldurması halinde -daha önce bilgilendirilmiş bulunsa da- TMK 436/b.2 hükmü çerçevesinde derhal bilgilendirilmesi yönüne gidilmelidir ${ }^{192}$; itiraz hakkına dikkati çekilmelidir.

-İtirazın İletilmesi

TMK 436/b.3 hükmüne göre "mahkeme kararını gerektiren her istem, gecikmeksizin yetkili hakime ulaştırılır". Bu hükümden maksat, kaynak Art. 397e Ziff.3 ZGB hükmü göz önünde bulundurulduğunda, esasen vesayet makamının koruma amacıyla özgürlüğün kısıtlanması sonucunu doğuran (kuruma yerleştirme, kurumda alıkoyma veya kurumdan çıkarılma talebinin reddi) kararlarına yönelik itirazın yetkili denetim makamına ulaştırılmasını sağlamaktır ${ }^{193}$. Buna göre itiraz talebinin yanlış mercie veya kişiye, mesela kurumda görevli personelden birine yöneltilmesi halinde, bu merci veya kişi tarafindan gecikmeksizin yetkili denetim makamına iletilmesi gerekmektedir. Vesayet altındaki küçük bakımından ele alındığında; burada küçük onaltı yaşını doldurmuş bulunmasa da koruma amacıyla özgürlügün kısıtlanması kararına itiraz ettiği takdirde, bu talep yetkili denetim makamına iletilmelidir ${ }^{194}$. Talebin geçerli olarak incelenip incelenmeyeceğine yetkili denetim makamı karar verir ${ }^{195} 196$.

TMK 436/b.4 hükmüne göre "yerleştirme kararı veren vesayet makamı veya hakim durumun özelliklerine göre bu istemin görüşülmesini erteleyebilir". Bu hüküm, TMK 436/b.3 hükmüyle birlikte kaynak Art. 397e Ziff.4 ZGB hükmü dikkate alınarak değerlendirilmelidir ${ }^{197}$. Buna göre TMK 436/b.4 hükmündeki “istem"den maksat, koruma amaciyla özgürlügün kısıtlanması kararına itiraz talebi olup, TMK 436/b.4 hükmüyle öngörülen

191 Krş., Müller, s. 324; BSK ZGB I- Geiser, Art. 405a N 12.

192 Krş., BSK ZGB I- Geiser, Art. 405a N 12; Lustenberger, s. 125.

193 Krş., Dural/Öğüz/Gümüş, s. 708-709. İsviçre hukukunda konuya ilişkin olarak Imhof, s. 96 vd.; BSK ZGB I- Geiser, Art. 397e N 13; ZK- Spirig, Art. 397 e N 116 vd.; Suhr Brunner, 149; Müller, s. 324-325; BBl 1977 III 39 vd.

194 Krş., BSK ZGB I- Geiser, Art. 405a N 12; Müller, s. 325; Dural/Öğüz/Gümüş, s. 634.

195 Krş., BSK ZGB I- Geiser, Art. 405a N 12.

196 Türk hukuku bakımından vesayet makamına yönelik taleplerin de (mesela kurumdan çıkarılma talebinin) bu hükmün kapsamında değerlendirilmesinin gerekip gerekmediğine ilişkin olarak Dural/Öğüz/Gümüsş, s. 709; bu hususta bkz., Akıntürk, s. 508; Çavuşoğlu Işıntan, Pelin: "Türk Hukukunda Yeni Bir Müessese: Koruma Amaciyla Kişi Özgürlügünün Kısıtlanması”, Galatasaray Üniversitesi Hukuk Fakültesi Dergisi, 2/2002, s. 305.

197 Krş., Dural/Öğüz/Gümüşs, s. 709 vd. 
husus şudur ${ }^{198}$; koruma amacıyla özgürlüğün kısıtlanması kararına itiraz edilmesi halinde, bu kararı veren vesayet makamı veya itirazı inceleyen denetim makamı, mevcut şartlar çerçevesinde uygun gördüğü takdirde koruma amacıyla özgürlüğün kısıtlanması kararının yerine getirilmesini erteleyebilir. Şu halde itiraz yoluna başvurulması, kanun gereği koruma amacıyla özgürlüğün kısıtlanması kararının yerine getirilmesini ertelemez ${ }^{199}$. Diğer bir ifadeyle ertelenmediği takdirde koruma amaciyla özgürlüğün kısıtlanması kararı, şekli anlamda kesinleşmemiş bulunsa dahi uygulanabilir niteliktedir; bundan maksat, özgürlüğü kısıtlanan kişiye, ihtiyaç duyduğu korunma ve desteğin derhal sağlanabilmesidir ${ }^{200}$. Vesayet altındaki küçük bakımından ele alındığında; burada küçük hakkındaki koruma amacıyla özgürlüğün kısıtlanması kararının derhal yerine getirilmesinin gerekip gerekmediği, diğer bir ifadeyle durumun acil olup olmadığ 1 ve bu bağlamda söz konusu kararın yerine getirilmesinin ertelenebilirliğii, küçügün özel korunma ihtiyacına göre belirlenir ${ }^{201}$.

\section{-Resmi Sağlık Kurulu Raporu Alınması}

TMK 436/b.5 hükmünde akıl hastalığı, akıl zayıflığı, alkol veya uyuşturucu madde bağımlılığı, ağır tehlike arz eden bulaşıcı hastalığı olanlar hakkında, ancak resmi sağlık kurulu raporu alındıktan sonra koruma amacıyla özgürlüğün kısıtlanması kararı verilebileceği öngörülmüştür. Yine anılan hükme göre vesayet makamının daha önceden bilirkişiye başvurmuş olması halinde denetim makamı bundan vazgeçebilir. TMK 436/b.5 hükmü, vesayet altındaki küçük bakımından da uygulanır ${ }^{202}$.

\section{b. İtiraz ve Yargılama Usulü}

Vesayet altındaki küçüğün koruma amacıyla özgürlüğünün k1sıtlanması kararına itiraz, TMK 446/III hükmüyle birlikte TMK 446/II'de yapılan atıf bağlamında TMK 435 hükmü çerçevesinde incelenmelidir. TMK 435 hükmüne göre "kuruma yerleştirilen kişi veya yakınları, verilen karara karş1 kendilerine bildirilmesinden başlayarak on gün içinde denetim makamına itiraz edebilirler (f.1). Bu hak, kurumdan çıkarılma isteminin reddi halinde de kullanılabilir (f. 2)".

198 Krş., BSK ZGB I- Geiser, Art. 397e N 15 vd.; ZK- Spirig, Art. 397e N 139 vd.; Imhof, s. 101 vd.; Suhr Brunner, s. 150; Müller, s. 325 vd.; BBl 1977 III 42; Dural/Öğüz/Gümüş, s. 709 vd.; Öztan, s. 809.

199 Krş., BSK ZGB I- Geiser, Art. 397e N 15.

200 Krş., BSK ZGB I- Geiser, Art. 397e N 16.

201 Krş., BSK ZGB I- Geiser, Art. 405a N 12; Müller, s. 326.

202 Krş., Dural/Öğüz/Gümüş, s. 634; İsviçre hukuku bakımından bkz. ve krş., BSK ZGB IGeiser, Art. 405a N 12; Müller, s. 326 vd. 
İtiraza konu oluşturan kararlar, koruma amaciyla özgürlüğün kısıtlanması sonucunu doğuran kararlardır ${ }^{203}$. Buna göre küçüğün bir kuruma yerleştirilmesini veya orada alıkonulmasını öngören kararlara itiraz edilebilir; yine TMK 435/II hükmünde açıkça belirtildiği gibi küçüğün kurumdan çıkarılma talebinin reddine yönelik kararlara da itiraz mümkündür.

TMK 435/I hükmü çerçevesinde kuruma yerleştirilen vesayet altındaki küçük veya küçüğe yakın kişiler, koruma amacıyla özgürlüğün kısıtlanması kararına itiraz edebilirler. Küçüğün itirazda bulunabilmesi için her şeyden önce ayırt etme gücüne sahip olması gerekir ${ }^{204}$. Burada küçügü̈n karş1 yöndeki iradesine rağmen bir kurumda yaşaması gerektiğinin veya yaşadığının farkında olması ve bunu ifade edebilmesi halinde, ayırt etme gücünün bulunduğu kabul edilir ${ }^{205}$. Öte yandan itiraz hakkını kullanabilmesi için küçügün ayrıca TMK 446/III hükmü uyarınca onaltı yaşını doldurmuş bulunması da gerekir. Lustenberger, bu yaş sınırının pratik sebeplerle kabul edildiğine işaret etmektedir ${ }^{206}$; burada kanunkoyucu, itiraz yetkisini net bir çizgiyle sınırlandırmak istemiştir; bu suretle küçüklerin itirazında onların ayırt etme gücünün açıklığa kavuşturulmasına ilişkin zahmetli araştırmalara gerek kalmaması hedeflenmiştir; sonuçta İsviçre'de dini erginlik yaşı olan onaltı yaşta karar kılınmıştır. Nitekim doktrinde bu yönde onaltı yaş sınırının, küçüğün sahip olması gereken ayırt etme gücünün derecesi bakımından kanuni bir tutamak noktası teşkil ettiği ifade edilmektedir ${ }^{207}$. Kanımızca TMK 446/III hükmü tartışılması gereken bir hükümdür. Bu hükümde koruma amacıyla özgürlüğü kısıtlanan küçüğün itiraz hakkını bizzat kullanabilmesi için onaltı yaşını doldurmuş bulunması şartının

203 Bu hususta bkz. ve krş., BSK ZGB I- Geiser, Art. 397d N 3, N 6; ZK- Spirig, Art. 397d N 29 vd.; Imhof, s. 127 vd.; Tuor/Schnyder/Rumo-Jungo, s. 517; Müller, s. 318; BBl 1977 III 36 vd.; BGE 112 II 104; Kılıçoğlu, s. 166; Öztan, s. 808; Akıntürk, s. 507. İsviçre doktrininde koruma amacıyla özgürlüğün kısıtlanmasının reddi veya kurumdan çıkarılma talebinin kabulü yönündeki kararlara karşı Art. 397d ZGB / TMK 435 hükmüne göre itiraz edilemeyeceği görüşü hakimdir (Bkz., Imhof, s. 129 vd.; BSK ZGB I- Geiser, Art. 397d N 6, Art. 405a N 15; ZK- Spirig, Art. 397d N 39 vd.); buna karş1lık söz konusu kararlara karşı Art. 420 ZGB / TMK 461 hükmüne göre itiraz edilebilir (BSK ZGB I- Geiser, Art. 397d N 6, Art. 405a N 15; Imhof, s. 130-131). Türk hukuk doktrininde Gümüş'e göre koruma amacıyla özgürlüğün kısıtlanmasının uygulanmasını engelleyen veya sona erdiren vesayet makamı kararlarına karşı da TMK 435 uyarınca itiraz imkanı sağlanmalıdır (Dural/Öğüz/Gümüsş, s. 701).

204 Müller, s. 316; BSK ZGB I- Geiser, Art. 405a N 18; Imhof, s. 139; Dural/Öğüz/Gümüş, s. 634 .

205 Krş., Müller, s. 316; BSK ZGB I- Geiser, Art. 405a N 18, Art. 397d N 12; ZK- Spirig, Art. 397d N 12; Imhof, s. 139; BBl 1977 III 37; Dural/Öğüz/Gümüş, s. 702.

206 Lustenberger, s. 134, krş., s. 24.

207 Krş., Imhof, s. 139; ZK-Spirig, Art. 397d N 12; Müller, s. 316, dn.11. 
aranması, Yeni Medeni Kanun'un çocuğun kişiliğini daha çok dikkate almayı hedefleyen hükümleriyle çelişmektedir (Bkz., mesela TMK 339/III, 450). Türk kanunkoyucusu, TMK 450 ve 454 hükümlerinde yaptığ gibi burada da onaltı yaş sınırından ayrılabilirdi ${ }^{208}$. TMK 446/III hükmünde itiraz hakkını bizzat kullanabilmesi bakımından yaş sınırı getirilmeksizin sadece küçüğün ayırt etme gücünün ölçüt olarak alınması, doktrinde de haklı ifadesini bulduğu üzere ${ }^{209}$ daha isabetli olurdu.

Koruma amacıyla özgürlüğün kısıtlanması kararına küçüğün dışında, küçüğe yakın kişilerin de itiraz etmesi mümkündür ${ }^{210}$. Yakınların itiraz hakk1, küçüğün itiraz hakkından bağımsızdır ${ }^{211}$. Burada yakın kavramına, daha önce de genel olarak ifade edildiği gibi, koruma amaciyla özgürlüğü kısıtlanan küçükle belirli bir ilişki içinde olup, onun menfaatlerini korumak isteyen kişi çevresi dahildir ${ }^{212}$. Bu noktada açıktır ki yakın kişinin, koruma amacıyla özgürlüğün kısıtlanması kararının küçüğün menfaatine olup olmadığını ve buna göre karara itiraz hususunu değerlendirebilmesi için küçügü iyi tanıması, küçüğün gelişimini ve özel korunma ihtiyacını bilmesi gerekir $^{213}$. Yakın kişinin küçükle ilişkisi, fiilî veya hukuki düzeyde olabilir $^{214}$. Bu çerçevede mesela küçüğün ana babası, kardeşleri, akraba, arkadaş, okul vb. çevresi, vasi, kayyım, küçükle kişisel ilişki kurma hakkına sahip üçüncü kişiler, yakın olarak sayılabilir.

TMK 435/I hükmüne göre koruma amaciyla özgürlüğün k1sitlanmas1 kararına karşı itiraz süresi, on gündür. Bu süre, yine anılan hüküm uyarınca gerek koruma amacıyla özgürlüğü kısıtlanan küçük gerek yakınlar bakımından kendilerine bildirilmesinden itibaren başlar. TMK 435/I hükmüne ilişkin olarak Türk hukuk doktrininde yer alan açıklamaların da anılan hükümdeki düzenlemeye paralellik gösterdiği ifade edilebilir ${ }^{215}$. Farklı görüşteki Gümüş'e göre ise bu hükümde yakınlara yönelik bir bildirim yükümlülüğü öngörülmemiştir; bu yönde sözü edilen hükmün sanki kuruma yerleştirilen kişinin yakınlarına yönelik bir bildirim yükümlülüğü varmış intibaını yaratan lafzı yanıltıcıdır; hükümdeki bildirim, İsviçre hukukunda olduğu gibi sadece TMK 436/b.1'e göre ilgili kişiye yapılması

208 Krş., Dural/Öğüz/Gümüş, s. 634; ayrıca bkz., Kanun'un gerekçesi (Dn.1), s. 149.

209 Dural/Öğüz/Gümüş, s. 634.

210 Krș., BSK ZGB I- Geiser, Art. 397d N 13, Art. 405a N 18; Müller, s. 316 vd.; Imhof, s. 140 vd.; Dural/Öğüz/Gümüss, s. 634.

211 Krş., BSK ZGB I- Geiser, Art. 397d N 13-14.

212 Müller, s. 317; Lustenberger, s. 139 vd.; Imhof, s. 141, $142 \mathrm{vd.}$

213 Müller, s. 317; Lustenberger, s. 139 vd.

214 Müller, s. 317; Lustenberger, s. 140.

215 Bu hususta bkz., Öztan, s. 808; Kılıçoğlu, s. 166; Akıntürk, s. 507; Gençcan, s. 51; Çavuşoğlu Işıntan, s. 303. 
gereken yazılı bildirimi ifade eder ve bu bildirimin yakınlar ile ilgisi yoktur ${ }^{216}$. Gümüş'e göre yakınların itiraz hakk1, koruma amacıyla özgürlüğün kısıtlanması kararı hakkında bilgi sahibi oldukları andan itibaren başlar ${ }^{217}$.

TMK 435 hükmüne ilişkin gerekçede, bu maddenin İsviçre Medeni Kanunu'nun $397 \mathrm{~d}$ maddesinden aynen alındığ 1 ifade edilmiştir ${ }^{218}$. Daha önce TMK 436/b.1 hükmüne ilişkin açıklamalar çerçevesinde de değinildiği üzere TMK 435/I hükmüne karşılık gelen kaynak Art. 397d Abs. 1 hükmünde koruma amacıyla özgürlüğün kısıtlanması kararından etkilenen kişinin veya ona yakın bir kişinin karara karşı bildirimden itibaren on gün içinde yazılı olarak mahkemeye başvurabileceği düzenlenmesi yer almaktadır. Buna göre TMK 435/I metni ile Art.397d Abs. 1 metninin bire bir örtüştüğü söylenemez. Bu noktada TMK 435/I hükmündeki "kendilerine" ifadesinin kanunkoyucunun bilinçli bir tercihi mi olduğu, yoksa bir çeviri hatası mı teşkil ettiği $i^{219}$ sorusu ortaya çıkmaktadır. Gerekçede bu hususta açıklık yoktur; bilakis, yukarıda belirtildiği gibi, 435. maddenin Art. 397d ZGB hükmünden aynen alındığına işaret edilmektedir.

Şu halde burada İsviçre kanunkoyucusunun tutumu irdelenmelidir. İsviçre'de 1978 revizyonuna ilişkin kanun tasarısının izahında yakın kişiler için on günlük itiraz süresinin, kararın koruma amacıyla özgürlügü kısıtlanan kişiye bildirilmesinden itibaren işleyeceği hususu yer almıştır ${ }^{220}$.

Konuya ilişkin olarak -daha önce TMK 436/b.1 hükmüyle ilgili açıklamalarda da yer verildiği üzere- Geiser, Art. 397d Abs. 1'deki düzenlemeden bütün yakınların koruma amacıyla özgürlüğün kısıtlanması kararının kendilerine bildirilmesine yönelik bir talebe sahip oldukları sonucunun çıkarılamayacağı görüşünü ifade etmektedir ${ }^{221}$; burada yakın kişi için itiraz süresi, koruma amacıyla özgürlüğün kısıtlanması kararından haberdar olmasıyla birlikte işlemeye başlar. Yakın kişinin kararı herhangi bir biçimde öğrenmiş bulunması yeterlidir. Anılan yazara göre Kanun, burada bazı yakınlar bakımından itiraz süresi henüz işlememiş bulunacağındankoruma amacıyla özgürlüğün kısıtlanması kararının uzun süre şekli anlamda kesinleşmeyecek olmasını bilinçli bir biçimde göze almıştır ${ }^{222}$.

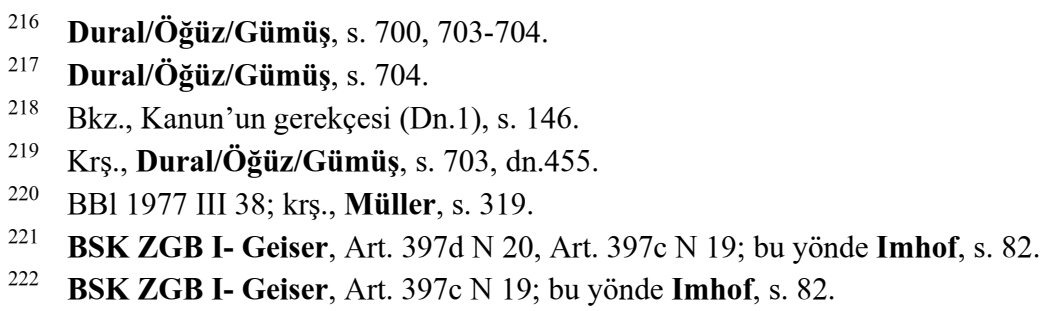


Meseleyi vesayet altındaki küçüğün koruma amacıyla özgürlüğünün kısıtlanması bakımından ele alan Müller'e göre ise on günlük itiraz süresi, koruma amacıyla özgürlügün kısıtlanması kararının yazılı olarak bildirildiği yakınlar için bildirimden itibaren başlar; buna karşılık kararın yazılı olarak bildirilmediği yakınlar için on günlük itiraz süresinin başlangıç tarihi, kararın küçüğe bildirildiği tarihtir ${ }^{223}$.

Kanımızca TMK 435/I hükmündeki düzenlemeden Geiser'in de ifade ettiği gibi bütün yakınların koruma amacıyla özgürlüğün kısıtlanması kararının kendilerine bildirilmesine yönelik bir talebe sahip oldukları sonucu çıkarılamaz; bu yönde bütün yakınlara yönelik bir bildirim yükümlülüğ̈̈nden söz etmek de mümkün görünmemektedir ${ }^{224}$. Ancak burada mesele, koruma amaciyla da olsa hakkında kişisel özgürlüğünün kısıtlanması kararı alınan kişiye, bu karara karşı denetim makamına itiraz imkanının sağlanmasıdır; bu suretle kararın denetim makamı nezdinde bir kere daha incelenmesi mümkün olacaktır. Bu itibarla özgürlüğü kısıtlanan kişinin, itiraz imkanından yararlanamayacağ 1 , diğer bir ifadeyle karara karşı itiraz hakkını kullanamayacağı bir halde, bunu gerçekleştirebilecek yakınlara bildirimde bulunulması zorunludur. Bu yönde mesela vesayet altındaki küçügün onaltı yaşını doldurmamış bulunması veya ayırt etme gücüne sahip olmaması halinde durum böyledir. Şu halde koruma amacıyla özgürlügün kısıtlanması kararının yakınlara bildirilmesi hususunun, her münferit halde somut olayın özelliklerine göre değerlendirilmesi gerektiği ifade edilebilir. Buna göre kararın yakınlara bildirilmesi halinde on günlük sürenin başlangıcı, bildirim tarihidir; aksi takdirde yakınlar için karardan herhangi bir biçimde haberdar oldukları tarih esas alınmalıdır.

Yukarıda TMK 435/I hükmü çerçevesinde vesayet altındaki küçük bakımından on günlük itiraz süresinin, kararın küçüğe bildirildiği tarihten itibaren başladığını ifade etmiştik. Ancak küçük, halihazırda bildirimden önce karardan haberdar olduğu takdirde, bildirimi beklemeksizin de itiraz yoluna başvurabilirr ${ }^{225}$. Öte yandan, daha önce de ifade edildiği gibi, koruma amacıyla özgürlüğün kısıtlanması kararı bildirilirken küçüğün itiraz hakkına ilişkin olarak bilgilendirilmesi gerekir; aksi takdirde küçük, her zaman itiraz edebilir ${ }^{226}$.

Küçüğün onaltı yaşını doldurmamış bulunması veya ayırt etme gücüne sahip olmaması halinde itiraz hakkı vasi ya da diğer yakınlar tarafindan kullanılabilir ${ }^{227}$. Burada vasi, itiraz hakkını kullanırken kendi adına veya

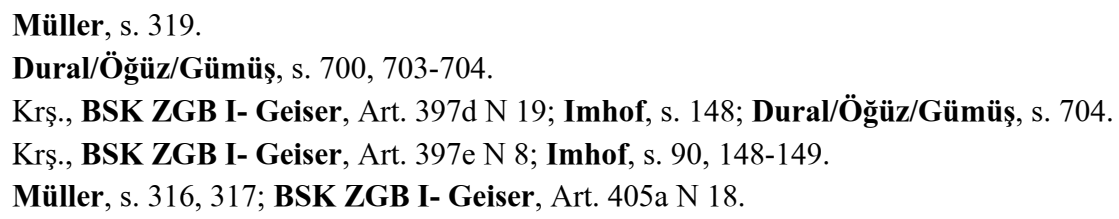


küçügün kanuni temsilcisi olarak hareket edebilir ${ }^{228}$. Doktrinde bunun pratik öneminin bulunmadığına işaret edilmektedir; her halükarda küçük, dava sürecine dahil olmaktadır ${ }^{229}$. Diğer taraftan TMK 426/b.2 anlamında vasi ile küçük arasında menfaat çatışmasının bulunduğu hallerde itiraz hakkının kullanılabilmesi bakımından küçüğe yakın diğer kişilere bildirim yapılması önemlidir. Somut olayda küçüğe yakın diğer kişiler mevcut bulunmayabilir veya itiraz hakkını kullanmaya muktedir olmayabilir; böyle bir halde kanımızca yukarıda da belirttiğimiz gibi küçüğe kayyım atanması yönüne gidilmelidir $^{230}$

On günlük itiraz süresinin geçirilmesinden sonra itiraz yoluna başvurulamaz; aksi takdirde itiraz talebi dinlenmez ${ }^{231}$. Buna karş1lık dürüstlük kuralına uygun olarak her zaman kurumdan çıkarılma talebinde bulunulabilitr $^{232}$. Bu bağlamda doktrinde de ifade edildiği üzere süresi geçirildikten sonra itirazda bulunulması halinde bu itiraz, kurumdan çıkarılma talebi olarak yetkili vesayet makamına iletilmelidir ${ }^{233}$.

TMK 437'de koruma amacıyla özgürlüğün kısıtlanmasında yargılama usulü düzenlenmiştir.

Anılan hükmün ilk fikrasına göre hakim, basit yargılama usulüne göre karar verir. Bu fikra hükmü, Türk hukuku bakımından hem vesayet makamı hem denetim makamı için geçerli olmalıdır ${ }^{234}$.

TMK 437/II'de yarg1lama sürecinde gerektiğinde ilgili kişiye adli yardım sağlanacağı hususu hükme bağlanmıştır. İlgili kişiden maksat, hakkında koruma amacıyla özgürlüğün kısıtlanması kararı alınacak kişi veya halihazırda böyle bir karar alınmış bulunan kişidir ${ }^{235}$. TMK 437/II hükmü çerçevesinde adli yardım bağlamında özellikle ilgili kişinin yargılama sırasında bir avukat tarafından temsil edilmesi imkanının sağlanmasına ișaret etmek gerekir ${ }^{236}$. Bu husus vesayet altındaki küçük bakımından ele alındığında; burada somut olayda şartlar gerektirdiği takdirde, mesela küçügün kendi haklarını mahkemede savunamaması halinde, onun bir avukat

228 BSK ZGB I- Geiser, Art. 405a N 18; Müller, s. 317.

229 BSK ZGB I- Geiser, Art. 405a N 18.

230 Krş., koruma amacıyla özgürlüğün kısıtlanması kararının sebeplerine ve itiraz hakkına ilişkin bilgilendirme bağlamında Lustenberger, s. 119 vd.; ayrıca Imhof, s. 199.

231 Krş., BSK ZGB I- Geiser, Art. 397d N 21; ZK- Spirig, Art. 397d N 50; Imhof, s. 149.

232 Krş., Imhof, s. 136-137; BSK ZGB I- Geiser, Art. 397a N 28; ZK- Spirig, Art. 397d N 63; BGE 130 III 729 (730).

233 Krş., BSK ZGB I- Geiser, Art. 397d N 21; ZK- Spirig, Art. 397d N 50; Imhof, s. 149; Dural/Öğüz/Gümüsş, s. 704.

234 Krş., Dural/Öğüz/Gümüşs, s. 712.

235 Krş., BSK ZGB I- Geiser, Art. 397f N 13.

236 Bu hususta bkz., Kanun'un gerekçesi (Dn.1), s. 146; Öztan, s. 809; Gençcan, s. 49. 
tarafindan temsil edilmesi imkanı sağlanır ${ }^{237}$. Esasen TMK 437/II hükmüne dayanarak bizzat küçük de kendisine bir avukat tayin edilmesini isteyebilir ${ }^{238}$.

TMK 437/III'de ise hakimin karar verirken ilgili kişiyi dinleyeceği öngörülmüştür. Bundan maksat hakimin, ilgili kişi hakkında kendi kanaatini oluşturmasıdır; burada hakim, somut olayda ilgili kişinin koruma amacıyla özgürlüğünün kısıtlanmasının gerekliliği hususunda bağımsız olarak kanaate ulaşmalıdı2 ${ }^{239}$. İsviçre hukukunda hakimin, ilgili kişiyi ayırt etme gücünün bulunmaması halinde de dinlemesi gerektiği ifade edilmektedir ${ }^{240}$. Burada mesele, yukarıda da belirtildiği gibi, hakimin ilgili kişi hakkında kişisel bir kanaate ulaşmasıdır; esasen anılan hükmün birincil amacı da budur ${ }^{241}$. TMK 437/III hükmü vesayet altındaki küçük bakımından ele alındığında; hakim, karar vermeden önce küçüğü bizzat dinlemelidir ${ }^{242}$. Burada TMK 446/III hükmünün sınırlayıcı etkisi söz konusu değildir ${ }^{243}$; diğer bir ifadeyle küçügün dinlenilmesi için onaltı yaşını doldurmuş bulunması aranmaz. Küçüğün dinlenilme şekli, küçüğün içinde bulunduğu somut duruma uyarlanmalıdır $^{244}$. Bu esnada küçüğün yararı gözetilmelidir; bu yönde küçügün yararını zedeleyebileceği hallerde küçüğün dinlenilmesinden vazgeçilebilirr ${ }^{245}$. Öte yandan küçüğün yaşı, hastalığ 1 dolayısıyla veya kişiliğinden kaynaklanan ya da diğer önemli sebeplerle dinlemenin mümkün olmadığ 1 hallerde dosyadaki belgelere göre karar verilebilir ${ }^{246}$. Hakim, gerekli görürse küçüğün yanı sıra vasi veya küçüğün yanlarında kaldığı aile vb. küçükle ilgili diğer kişileri de dinler ${ }^{247}$.

\section{Sonuç}

Buraya kadar yaptığımız açıklamalar çerçevesinde vardığımız sonuçları şöyle ifade edebiliriz:

237 Krş., Müller, s. 328 vd.; BSK ZGB I- Geiser, Art. 405a N 20, Art. 397f N 14.

238 Krş., BSK ZGB I- Geiser, Art. 405a N 20.

239 Krş., Müller, s. 329, 330 vd.; BSK ZGB I- Geiser, Art. 405a N 19, Art. 397f N 19; ZKSpirig, Art. 397f N 104; BBl 1977 III 40; ayrıca bkz., Kılıçoğlu, s. 168.

240 Imhof, s. 207; ZK- Spirig, Art. 397f N 108; Lustenberger, s. 148; Müller, s. 330; BB1 1977 III 40; ayrıca bkz., BK- Schnyder/Murer, Art. 374 N 86; krş., Kılıçoğlu, s. 168.

241 Lustenberger, s. 148; krş., Imhof, s. 204 vd.; ZK- Spirig, Art. 397f N 104.

242 Müller, s. 329 vd., 331; BSK ZGB I- Geiser, Art. 405a N 19, Art. 397f N 20; Dural/Öğüz/Gümüsş, s. 634.

243 Krş., BSK ZGB I- Geiser, Art. 405a N 19; Dural/Öğ̈̈̈z/Gümüş, s. 634.

244 Krş., Lustenberger, s. 150; BGE 131 III 409 (413).

245 Krş., Lustenberger, s. 149; BGE 131 III 409 (413).

246 Krş., BSK ZGB I- Geiser, Art. 397f N 23, Art. 397d N 25; ZK- Spirig, Art. 397f N 114; Imhof, s. 208; BGE 116 II 406.

247 Müller, s. 331; Lustenberger, s. 150, 151 vd.; ayrica bkz., Öztan, s. 809. 
Vesayet altındaki küçüğün koruma amacıyla özgürlüğünün kısıtlanmasına ilişkin TMK 446 hükmü, 4721 sayılı Türk Medeni Kanunu'nun getirdiği yeni bir düzenlemedir. Bu düzenleme ile küçügün koruma amacıyla bir kuruma yerleştirilebileceği öngörülmüş bulunmaktadır.

Koruma amacıyla küçügün özgürlüğünün kısıtlanması, vesayete ilişkin bir önlem olup, esasen küçüğün kişisel özgürlük hakkına yönelik bir müdahaleyi ifade eder. Burada küçüğün kişisel özgürlügüne yönelik müdahale, küçüğün iradesine karşı veya iradesi bulunmaksızın kamu gücüne dayanılarak bir kuruma yerleştirilmesi suretiyle gerçekleşir. Öte yandan yerleştirildiği kurumda küçüğün kişisel özgürlüğü, ortalama bir ailede bulunan yaşıtınınkine göre daha çok kısıtlanmış olmalıdır.

Küçüğün kişisel özgürlüğüne ağır bir müdahale olarak küçüğün koruma amacıyla bir kuruma yerleştirilmesi, belirli şartların varlığını gerektirir. Ancak TMK 446 hükmünde vesayet altındaki küçüğün koruma amacıyla özgürlüğünün hangi şartlar altında kısıtlanabileceği belirtilmemiştir.

Bununla birlikte küçüğün koruma amaciyla özgürlüğünün kısıtlanmasının şartlarının vasinin küçüğe özen gösterme yükümü ile bağlantılı olarak belirlenmesi mümkündür; zira gerek özen yükümü gerek koruma amacıyla özgürlüğün kısıtlanması ile amaçlanan, küçüğün ihtiyaç duyduğu korunma ve desteğin sağlanarak küçüğün yararının gerçekleştirilmesidir. Koruma amacıyla özgürlügün kısıtlanmasında küçüğün korunma ve destek ihtiyacının, onun uygun bir kuruma yerleştirilmesi suretiyle karşılanması söz konusudur ve esasen somut halde küçüğün kişisel korunması başka şekilde sağlanamadığı içindir ki koruma amacıyla özgürlügün kısıtlanması yoluna başvurulmaktadır. $\mathrm{Bu}$ noktada koruma amacıyla özgürlüğün kısitlanması, özen yükümünün gereklerinin yerine getirilebilmesi açısından başvurulabilecek son çareyi (ultima ratio) oluşturur ve vasinin özen yükümünü tamamlayıcı bir işlev gösterir.

Öte yandan Avrupa İnsan Hakları Sözleşmesi'nin küçüklerde özgürlüğün kısıtlanmasına ilişkin hükmü (m. 5/I-d) ve Anayasa'nın 19. maddesi hükmü çerçevesinde küçügün kuruma yerleştirilmesi, onun gözetim altında eğitimi amacına yönelik olmalıdır; diğer bir ifadeyle küçüğün kurum düzeni içinde gözetim altında eğitimi gerekli görülmelidir.

Nihayetinde küçüğün koruma amacıyla özgürlüğünün kısıtlanabilmesi için somut haldeki korunma ihtiyacının karşılanabileceği uygun bir kurumun bulunması gerekir. Kurumun uygunluğundan maksat, kurumun ideal olmas1 değildir; burada söz konusu olan, kurumun somut halde küçük için en uygun alternatifi teşkil etmesidir. Kurum, küçük için gerekli korunma ve desteği sağlayabilecek organizasyona ve nitelikli personele sahip olmalıdır. 
Vurgulanması gereken bir husus da şudur ki vesayete ilişkin bir önlem olarak koruma amacıyla özgürlügün kısıtlanması, her aşamada ölçülülük ilkesine uygun bir biçimde gerçekleştirilmelidir. Esasen kuruma yerleştirilebilmesi için somut halde küçüğün kişisel korunmasının başka şekilde sağlanamaması ve küçüğü koruma amacı bakımından elverişli (uygun) bir kurumun bulunması gereği, ölçülülük ilkesinin açık ifadesidir.

TMK 446/I hükmü uyarınca küçügün koruma amacıyla bir kuruma yerleştirilmesine vasinin başvurusu üzerine vesayet makamı karar verir; gecikmesinde sakınca bulunan hallerde ise bizzat vasi karar verir ve durumu derhal vesayet makamına bildirir. TMK 446/I hükmü çerçevesinde vasinin tek başına aldığı kararın geçerli olması için vesayet makamının onayı gerekli değildir; burada eski Medeni Kanun'da olduğu gibi Yeni Medeni Kanun'da da yer alan ve vesayet altındaki kişinin bir eğitim, bakım veya sağlık kurumuna yerleştirilmesi halinde vesayet makamının iznini arayan TMK 462/b.13 hükmünün uygulamasının bulunmadığı kabul edilmelidir. TMK 446/I'de gecikmesinde sakınca bulunan hallerde küçügün kuruma yerleştirilmesine bizzat karar verebilme suretiyle vasiye olağanüstü bir yetki tanınmıştır. Bununla küçüğün acil korunma ihtiyacının doğrudan vasinin aldığ 1 ve vesayet makamının onayını gerektirmeksizin geçerliğe sahip bir karara dayanılarak derhal karşılanması mümkün olmaktadır; bu, pratik bir çözümdür. Öte yandan vasinin durumu, vesayet makamına derhal bildirme yükümlülügü dolayısıyla da vesayet makamının kendiliğinden harekete geçme imkanı mevcuttur. Şu halde uygulaması bulunmayan bir hüküm olarak TMK 462/b.13 hükmünün Kanun metninden çıkarılmas1 gerekir.

Öte yandan gecikmesinde sakınca bulunan hallerde vesayet makamı da kendiliğinden harekete geçerek küçüğü doğrudan kuruma yerleştirebilmelidir. Burada önemli olan, küçüğün acil korunma ihtiyacının derhal karşılanmasıdır.

Bize göre TMK 446/III hükmü kanunkoyucu tarafindan yeniden ele alınmalıdır. Bu çerçevede anılan hükümde yer alan onaltı yaş sınırından vazgeçilmelidir. Burada küçügün koruma amaciyla özgürlüğünün kısıtlanması kararına karşı denetim makamı nezdinde itiraz hakkını bizzat kullanabilmesi için sadece ayırt etme gücüne sahip olması şartı aranmalıdır. Kanımızca mesele şudur; küçüğe, kişisel özgürlüğüne ağır müdahale oluşturan böyle bir önleme karşı itiraz yoluna bizzat başvurabilme imkanı olabildiğince erken tanınmalıdır. Buna göre ayırt etme gücünün bulunması halinde küçüğün belirli bir yaşa erişmesinin beklenmesi, maksada aykırı düşer.

Diğer taraftan mevcut TMK 446/III hükmüne rağmen küçüğün ayırt etme gücüne sahip olması halinde -onaltı yaşını doldurmuş bulunmasa daTMK 436/b.1 ve b.2 hükümleri çerçevesinde uygun biçimde 
bilgilendirilmesi gerektiği görüşündeyiz. Küçüğün kişiliğine sayg1 gösterilmesi ilkesi, küçüğün koruma amaciyla da olsa kişisel özgürlüğünü kısıtlayan kararın sebepleri ve bu karara karşı hangi haklara sahip olduğu hususunda bilgilendirilmesini gerektirir.

Son olarak işaret etmek istediğimiz husus da şudur; her halükarda küçüğe, koruma amacıyla özgürlüğünün kısıtlanması kararına karşı gerekli hukuki koruma sağlanmalıdır. Buna göre küçügün onaltı yaşını doldurmuş bulunmaması veya ayırt etme gücüne sahip olmaması halinde, itiraz hakkının kullanılabilmesi bakımından vasi ve diğer yakınların bilgilendirilmesi önemlidir. Ancak somut olayda özellikle küçüğün bizzat vasi tarafından kuruma yerleştirilmesi sebebiyle TMK 426/b.2 anlamında vasi ile küçük arasında menfaat çatışmasının bulunduğu bir hal söz konusu olabilir; böyle bir durumda küçüğe yakın diğer kişiler de bulunmayabilir ya da itiraz hakkını kullanmaya muktedir olmayabilir; burada küçüğe kayyım atanması yönüne gidilmelidir. 


\section{KISALTMALAR}

aArt. : frühere Fassung des betreffenden Artikels

Abs. : Absatz

Art. : Artikel

b. : bent

BBl : Bundesblatt

BK- : Berner Kommentar

Bkz. : Bakınız

BSK- : Basler Kommentar

dn. : dipnot

Hrsg. : Herausgeber

Krş. : Karşılaştırınız

m. : madde

$\mathrm{N} \quad$ : Nummer

RG. : Resmi Gazete

S. : sayfa

SJZ : Schweizerische Juristen-Zeitung

Syst. Teil : $\quad$ Systematischer Teil

TBMM : $\quad$ Türkiye Büyük Millet Meclisi

TMK : Türk Medeni Kanunu

vb. : ve benzerleri

vd. : ve devamı

ZGB : Schweizerisches Zivilgesetzbuch

Ziff. : Ziffer

ZK- : Zürcher Kommentar

ZSR : Zeitschrift für Schweizerisches Recht 